\title{
Description of some Salticidae (Aranei) from the Malay Archipelago. II. Salticidae of Java and Sumatra, with comments on related species
}

\author{
Описание некоторых Salticidae (Aranei) из Малайского \\ Архипекага. II. Salticidae островов Ява и Суматра \\ с комментариям о близких видах
}

\author{
Jerzy Prószyński*, Christa L. Deeleman-Reinhold** \\ Й. Прушиньский*, К.А. Аеелеман-РейнхольА ${ }^{* *}$
}

\footnotetext{
* Museum and Institute of Zoology, Polish Academy of Sciences, ul. Wilcza 64, 00-679 Warszawa, Poland. E-mail: jerzy.proszynski@wp.pl

**4619GA Ossendrecht, the Netherlands. E-mail: cdeeleman@planet.nl
}

KEY WORDS: Salticidae, new species, diagnostic characters, geographical distribution, Indonesia, Java, Sumatra. КЛЮЧЕВЫЕ СЛОВА: новый вид, диагностические признаки, распространение, Индонезия, Ява, Суматра.

ABSTRACT. This paper describes two new genera (Junxattus gen.n. and Leuserattus gen.n.) and 12 new species from Sumatra and Java: Bathippus petrae sp.n., Donoessus kerinci sp.n., Emathis sumatranus sp.n., Heratemita tenenbaumi sp.n., Junxattus daiqini sp.n., Leuserattus gunung sp.n., Nannenus maughami sp.n., $N$. siedleckii sp.n., Orcevia kuloni sp.n., Orsima thaleri sp.n., Phintella conradi sp.n., Pseudicius javanicus sp.n., as well as first description of unknown female of Thianitara spectrum Simon, 1903. A related species Th. thailandica sp.n. is described from Thailand. Genus Orcevia Thorell, 1890 is removed from synonymy with Laufeia Simon, 1889, and following new combinations of SE Asian species created: Laufeia eucola $($ Thorell, 1890 $)=$ O. eucola Thorell, 1890, L. keyserlingi $($ Thorell, 1890$)=O$. keyserlingi Thorell, 1890, L. perakensis $($ Simon, 1901) $=$ O. perakensis Simon, 1901, L. proszynskii Song et al., $1988=O$. proszynskii (Song et al., 1988). comb.n. Taxonomic problems are discussed and new drawings added to the species Epeus flavobilineatus (Doleschall, 1859), Leikung porosa (Wanless, 1978), Mintonia tauricornis Wanless, 1984, Phaeacius fimbriatus Simon, 1900, and Taraxella sumatrana Wanless, 1987. The genus Emathis Simon, 1899 is redefined and its name restricted to the Southeastern Asian species only. Five Caribbean species earlier considered in Emathis are transferred into a new genus Petemathis gen.n.: $P$. luteopunctata (Petrunkevitch, 1930) comb.n, P. minuta (Petrunkevitch, 1930) comb.n., P. portoricensis (Petrunkevitch, 1930) comb.n (type species), P. tetuani (Petrunkevitch, 1930) comb.n. and P. unispina (Franganillo, 1930) comb.n.

РЕЗЮМЕ. Из Суматры и Явы описаны два новых рода Junxattus gen.n., Leuserattus gen.n. и 12 новых видов: Bathippus petrae sp.n., Donoessus kerinci sp.n., Emathis sumatranus sp.n., Heratemita tenenbaumi sp.n., Junxattus daiqini sp.n., Leuserattus gunung sp.n., Nannenus maughami sp.n., N. siedleckii sp.n., Orcevia kuloni sp.n., Orsima thaleri sp.n., Phintella conradi sp.n. и Pseudicius javanicus sp.n.. Впервые описана самка Thianitara spectrum Simon, 1903 и одновременно описан близкий вид из Таиланда Th. thailandica sp.n. Род Orcevia Thorell, 1890 выведен из синонимии с Laufeia Simon, 1889 соответственно восстановлены или установлены следующие комбинации: Laufeia eucola (Thorell, 1890) = O. eucola Thorell, 1890, L. keyserlingi (Thorell, 1890) = O. keyserlingi Thorell, 1890, L. perakensis (Simon, $1901)=$ O. perakensis Simon, 1901, L. proszynskii Song et al., $1988=O$. proszynskii (Song et al., 1988). comb.n. Обсуждается таксономический статус и приведены рисунки для Epeus flavobilineatus (Doleschall, 1859), Leikung porosa (Wanless, 1978), Mintonia tauricornis Wanless, 1984, Phaeacius fimbriatus Simon, 1900 и Taraxella sumatrana Wanless, 1987. Пересмотрены границы рода Emathis Simon, 1899. Установлено, что он включает виды только из Юго-Восточной Азии. Пять видов из Карибского бассейна, ранее относимых к Emathis, переведены в новый род Petemathis gen.n.: P. luteopunctata (Petrunkevitch, 1930) comb.n., P. minuta (Petrunkevitch, 1930) comb.n., P. tetuani (Petrunkevitch, 1930) comb.n. и $P$. unispina (Franganillo, 1930) comb.n.

\section{Introduction}

This is the second part in a series of papers dealing with Salticidae of the Malay Archipelago. Java and Sumatra together have records of 190 species of Salti- 
cidae, of which 55 have some sort of diagnostic drawings for both sexes, 62 species have only a single sex illustrated, and 54 have not been illustrated, although specimens are preserved in some collections so they could be redescribed in the future; 16 species are dubious. In addition to these rather poor statistics, the quality of the existing drawings is often insufficient for identification, nor for the separation of related species, while species without diagnostic drawings cannot be identified. Identifications and definitions of species in Salticidae are based on comparison with existing diagnostic drawings of Salticidae in the literature, as summarized in the internet database "Monograph of Salticidae (Araneae) of the World" by Prószyński [2011].

By providing comparative drawings, basic for identification, the present paper facilitates study of species not only from Java and Sumatra, but also for some species from a much broader area - particularly Borneo, the Malay Peninsula and even Thailand. A broad comparison of species also permits the rearrangement of several genera, especially Pseudicius Simon, 1885.

The methodology of taxonomic analysis in this paper deserves some consideration. It is a long taxonomic tradition to describe characters of animals in words, resulting in the tedious preparation of long texts, describing morphology of a species, in a number of languages, and boring study of such descriptions for the recognition of species. A refinement of that approach is summarizing the data of numerous morphological characters in cladograms, usually arranged with the help of specialized computer software. That results in descriptions devoid of drawings, or with diagrammatic illustrations only, which do not permit recognition of the species. The other method, suitable for the majority of Salticidae, is through the comparison of pictures of a species - with other pictures, or with actual specimens. This method requires some artistic skills for the preparation of drawings, or photographs, and the experienced eye of a taxonomist. Hence, it is rather difficult for beginners and people with poor picture perception. Recently, Benjamin [2004] characterized the usage of genitalic characters as "single character systems believed a priori to have greater importance than other characters" - in difference to the supposedly multicharacter approach of cladistic analysis, which is apparently more scientific. Palpus, epigyne and internal structures of the epigyne are "single characters", in the same way as photographs of a human face are single characters, although we recognize people by them. Photographs of faces cannot be easily translated into a written description, they are identified by comparison with the faces of other people, a natural way of recognition. In the same way drawings and/or photographs of palpi and epigynes should be used. There is no point in arguing which methodology is better, we are satisfied that "pictorial" methods define poorly known genera, species, and relationships.

This paper presents partial data on Salticidae kept in the C.L. Deeleman-Reinhold collection. These were preliminary drawings made in 1994-1997 of sample specimens. They were made available in the internet database, with the intention of a more detailed study of specimens and more species at a later date. Unfortunately, the opportunity for such complementary studies never occurred, so we have decided to publish our drawings and notes of 1990 s, as they are, in order to serve as useful data for salticid taxonomists.

The main aim of this paper is to provide preliminary reference diagnostic drawings to complement the scanty literature data for certain South East Asian salticid genera and species. The classification is provisional in some cases, pending revisions of related genera, especially their insufficiently studied type specimens. An untapped source of taxonomic information are photographs of Salticidae, available on the Internet, some of which are used in this paper to draw attention to particularly interesting species. The authors realize the limited sample sizes of the described material, but assume that they will promote future taxonomic research.

The best method of describing species is comparing them directly, usually by placing them together under a stereomicroscope, and comparing simultaneously particular characters, whilst at the same time documenting them by drawings or photographs. However, some characters of the studied specimens had deteriorated so much during years of storage that old and fresh specimens were difficult to compare. This is well illustrated by sets of photographs of both living and long preserved specimens of the same species, made by Koomen [Prószyński, 2011]. In addition, while females cannot be identified in many species without preparation of the epigyne, the preparation itself puts the organs in jeopardy: epigynes (and also palpus) stored in microvials are getting lost during subsequent examinations, while those mounted in Canada Balsam on microscope slides become so transparent that they cannot be seen without restoration (dissolving the Canada Balsam, staining the preparation and mounting them again as a permanent or temporary slide). The safest and best documentation of internal structures of the epigyne is perhaps the publication of good quality drawings, diagrammatic illustrations are useless.

There is no satisfactory standard terminology for the description of the internal structures of Salticidae epigynes, so the terminology I have used during the last 50 years was rather intuitive. However, there is an excellent publication on these structures in Lycosidae, published recently by Useta et al. [2007], which we try to follow in this paper. Some Salticidae (for instance Pseudicius spp., Thyene spp.) have such complicated epigynal internal structures that a Useta-style study of them would be highly beneficial.

With modern techniques available, the postulated methods of description should include: photographs of living (or freshly preserved) specimens and their genital organs, these photographs being published or made available in the internet. With photographs or drawings available, we can resign from the schematic descrip- 


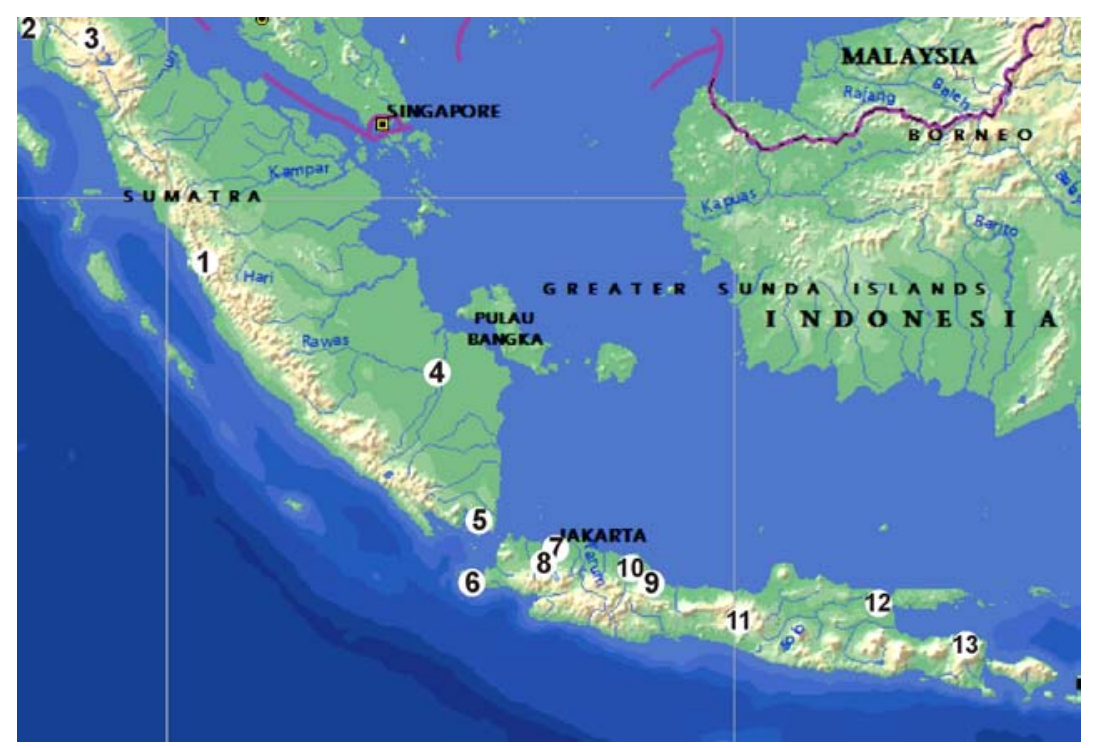

Map. Greater Sunda Islands: Collecting localities. Sumatra: 1 - Padang: Fort de Kock, Singalang, Kerinci; 2 - Bohorok, Gunung Leuser; 3 - Lake Toba; 4 - Palembang. 5 - Krakatau Is. Java: 6 - Udjung Kulon, 7 - Jakarta, 8 Bogor, Tjibulan, 9 - Kagok, 10 - Palembang; 11 - Wonosobo, 12 - Tenger, 13 - Baluran.

Карта. Большие Зондские острова: Места сборов: Суматра: 1 - Паданг: Fort de Kock, Singalang, Kerinci; 2 Богорок, Gunung Leuser; 3 - оз. Тоба; 4 - Палембанг. 5 - о-в Кракатау. Ява: 6 Уджунг Кулон, 7 - Джакарта, 8 Богор, Tjibulan, 9 - Кагок, 10 - Палембанг; 11 - Вонособо, 12 - Танжер, 13 - Балуран. tion of body characters, reducing them to shorter descriptions which differentiate species based on real and observable differences.

\section{Materials and methods}

Specimens were studied under a stereomicroscope, with magnification up to $100 \mathrm{x}$ (with an additional $2 \mathrm{x}$ objective lens giving 200x). Palpi were detached from the body and fixed for examination in sand on the bottom of a Petri dish filled with $75 \%$ ethanol. After examination the palpi were placed in micro vials and stored with specimen in the same collection vials. The epigyne was drawn from the intact specimen, and then cut off for examination of the internal structure. The tip of a small scalpel was slid under the epigyne, then the integument around it was cut. The epigynal plate was placed in 10-20\% aqueous $\mathrm{KOH}$ solution and cleared for 24-72 hours (at room temperature), later stained in Chlorazol Black E alcohol solution, mounted on a temporary slide in clove oil, and examined under a compound microscope (objectives 20x and for details 40x). After examination, the epigyne was deposited in a microvial and stored together with the specimen. All drawings were made with a square net micrometer (ocular graticule with squares) on paper with a temporary faint grid (with dimension selected to fit the requested drawing size). All measurements are in $\mathrm{mm}$.

The research was done during the years 1994-1997 on specimens singled out from the collection of C.L. Deeleman-Reinhold as particularly interesting, with the intention of conducting additional research later on. Unfortunately, the opportunity for such complementary studies never occurred, so here we present only these drawings and other data preserved in our files. That makes the present text somewhat laconic and incomplete. In addition, we add relevant drawings of related species and commentaries on literature published since our studies. The collection has been donated to the National Natuurhistorische Museum ("Naturalis") (formerly Rijksmuseum van Natuurlijke Historie) in Leiden, the Netherlands, but is physically still stored at the home of C.L. Deeleman-Reinhold in Ossendrecht. The holotypes are marked in the collection by red chips, paratypes by blue chips.

AMNH - American Museum of Natural History, New York, USA.

CAS - California Academy of Sciences, San Francisco.

CDML - Collection of C.L. Deeleman-Reinhold, donated to Rijksmuseum Leiden, but physically still stored in her home in Ossendrecht (2011).

IRRI - International Rice Institute, Los Banos, the Philippines.

MiIZ - Museum and Institute of Zoology PAN, Warsaw, Poland. Italy.

MCSN — Museo Civico di Storia Naturale, Genoa,

MCZ - Museum of Comparative Zoology, Harvard University, USA.

MNHN - Muséum National d'Histoire Naturelle, Laboratoire de Zoologie (Arthropodes), Paris.

NHMW - Naturhistoriches Museum, Wien

NHRS - Natural History Museum, Stockholm.

PMYU — Peabody Museum, Yale University, New Haven, USA.

As comparative material, we included unpublished diagnostic photo-documentation by Koomen (displayed in Prószyński [2011]). Such images have huge potential value, and we highly recommended taxonomists to utilize these in their future research. 


\section{Taxonomic survey}

\section{Genus Bathippus Thorell, 1892}

REMARKS. The genus Bathippus contains 41 nominal species, of which only 21 have some kind of published diagnostic drawings and/or photographs [Prószyński, 2011]. It is characterized by an elongate body with a high carapace, males have enormously elongated chelicerae and a Euophryinae type of palpus. There is an unresolved problem regarding the relationship with the similar looking genus Canama Simon, 1903, which differs by a minute fork on one of cheliceral teeth [Prószyński, 1984b: 5-11; Davies \& Żabka, 1989: 220, pl. 29].

\section{Bathippus petrae sp.n.}

$$
\text { Figs 1-9. }
$$

MATERIAL. Holotype $\sigma^{7}$, allotype $1 \uparrow$, Sumatra: Bohorok, 23 April, 1983 + riverside 17 November, 1983. Leg. S. Djojosudharmo. CDML. [Specimens labeled Bathippus ef. shelfordi in the collection].

ETYMOLOGY. Named after Dr. Petra Sierwald, who was the first to introduce me, in 1986, to the beneficial use of computers, influencing the subsequent research on Salticidae by myself and my colleagues in Poland.

DIAGNOSIS. Differs from the closely related $B$. rectus Zhang, Song, Li, 2003 [Zhang et al., 2003: f. 4ac] from Singapore, by a broader bulbus and coil of the embolus, inclined tibial apophysis (Fig. 6); also abdominal pattern (Fig. 1) is different.

DESCRIPTION. Male. Carapace high and broad, slope of thorax begins immediately behind eyes III. Abdomen low, narrow and twice as long as the carapace. Abdominal pattern consists of three pairs of darker marginal spots on lighter background, spinnerets dark (Fig. 1). Chelicerae elongate and bent, dentition as in Fig. 3. Leg I with mane of short, dark setae on femur I dorsally and ventrally on patella I (Fig. 4). Spines of tibia and metatarsus I are shown in Fig. 5.

Palpus typical for Euophryinae, with meandering spermophor duct and coiled embolus (forming one and half coils) (Figs 7-8).

Female. Somatic characters are not documented. In the epigyne a pair of elongate oval grooves is separated by a narrow septum, copulatory openings posterior (Fig. 8). Spermathecae large, oval, narrowing anteriorly. The copulatory ducts in front of spermathecae sclerotized with broad walls and minute scent opening at the characteristic bend, they change into a membranous structure encircling the spermathecae externally (Fig. 9). Pores of the nutritive opening indistinct, in the anterior part of the spermatheca.

REMARK. Related also to $B$. shelfordi Peckham \& Peckham, 1907 from Borneo and B. palabuanensis Simon, 1902 from Java.

DISTRIBUTION. Documented from Indonesia: Sumatra.
Genus Donoessus Simon, 1902

Type species Hasarius nigriceps Simon, 1899 from Sumatra.

REMARK. The existing data on the genus Donoessus Simon, 1902 are uncertain, so the genus deserves taxonomic revision. There are only two species listed in Catalog by Platnick [2011]. The type species - $D$. nigriceps is known to us only from the specimen from Mentawai: Sipora (an Archipelago off West Sumatra), in the collection of Reimoser (Figs 20-22), but its conspecificity with Simon's original specimen was not checked. Better known species D. striatus Simon, 1902 from Borneo serves us for comparison with the new species from Sumatra, described below. Tangible differences are light transverse bars on the abdomen (Figs 10, 16), separated by darker ones, also light broad diamond spot behind eyes. They are particularly striking on photograph by P. Koomen [Prószyński, 2011] of a fresh specimen from Borneo. Palpi of males in this genus are rather similar, with small differences of uncertain taxonomic value. Epigyne in this genus also looks similar, but internal structure of newly described species looks promising for diagnostic purposes.

DISTRIBUTION. Indonesia: Mentawai Island, Sumatra; Malayasia: Borneo: Sabah.

\section{Donoessus kerinci sp.n.}

Figs 10-14, 18-19.

MATERIAL. + holotype, $\sigma^{7}$ allotype, Sumatra: Kerinci National Park, near river, from leaves, 20-30 July, 1988. Leg. S. Djojosudharmo. CDML.

ETYMOLOGY. Named for Kerinci National Park in Sumatra, where it was collected.

DIAGNOSIS. Differs from D. striatus Simon, 1902 by the arrangement of white and dark spots on the carapace and abdomen (Figs 10 and 16). Female epigyne (Fig. 18) differs from D. nigriceps (Fig. 20) by more anterior position of epigynal "windows". Male differs by details of the palpal organ (Figs 13-14 cf. 21-22).

DESCRIPTION. Male. Dorsal aspect shown in Fig. 10; remnants of abdominal dark bars are directed posteriorly. Cheliceral dentition bifid (Fig. 12), resembles drawing by Simon [1903a: 772, f. 928-929] but its diagnostic value is uncertain. Palpal organ with broad, meandering spermophor duct, typical for Euophryinae. There is a large, half disc-shaped basal structure to the embolus (Fig. 13), with diameter equal to one third the length of the bulbus. The embolus appears as a free extension of the disc and extends over one half of the cymbium tip, anteriorly to the bulbus. There is a black process of unknown function, anteriorly to the disc. According to one interpretation it could be the ascending part of the embolus coil, and it was interpreted as such for D. striatus, as shown in Fig. 15. Lateral view of palpal organ (Fig. 14) does not clarify the issue because it shows two thin anterior processes and it is uncertain which of them is actually the embolus. 


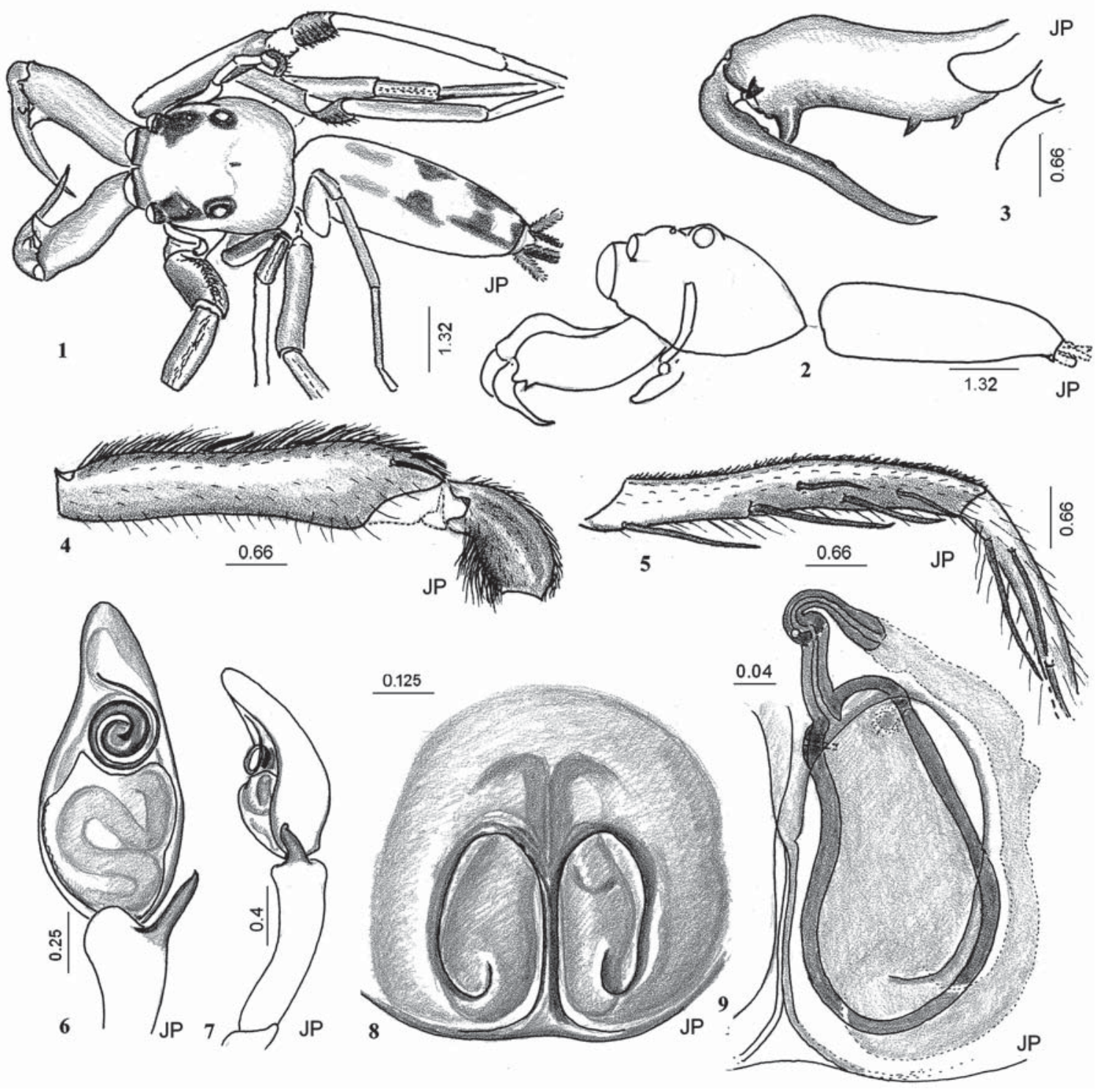

Figs 1-9. General appearance and copulatory organs of Bathippus petrae sp.n. from Sumatra, Bohorok: 1-2 - general appearance of male, dorsal and lateral views; 3 - chelicera; 4 - leg I: femur and patella 5 - leg I: tibia and metatarsus; 6-7 - palpus ventrally and laterally; 8-9- epigyne and its internal structure.

Рис. 1-9. Внешний вид и копулятивные органы Bathippus petrae sp.n. из Суматры, Богорок: 1-2 - Внешний вид самца, дорзально и сбоку; 3 - хелицера; $4-$ нога I: бедро и колено; 5 - нога I: голень и предлапка; 6-7 -пальпа снизу и сбоку; 8-9эпигина и её внутреннее строение.

Female. Somatic characters are not documented. Epigyne (Fig. 18) with a pair of large oval, membranous windows with sclerotized rims. Spermatheca (Fig. 19) specific, two chambered, with small scent opening armature atop the first chamber, and large depression with nutritive pores in the second one. Copulatory opening sclerotized, opens directly to first chamber of spermatheca, so that structure may also be interpreted as a large, swollen copulatory duct. Lack of comparative drawings for other related species makes a clear interpretation impossible.

REMARKS. Embolar basal disc is characteristic for males in all species of Donoessus but its interpreta- tion is uncertain, because not enough attention was paid to these structures previously. As there are no more drawings of these details in the literature, the clarification of this issue must await further research. A female is designated as the holotype because the epigyne and its internal structures are more distinctive than those of the male palp.

\section{Donoessus striatus Simon, 1902}

Figs $15-17$.

D. s. Simon, 1902: $376\left(\sigma^{7}\right)$.

D. s.: Simon, 1903a: 772, f. 928-929 $\left(\sigma^{7}\right)$. 

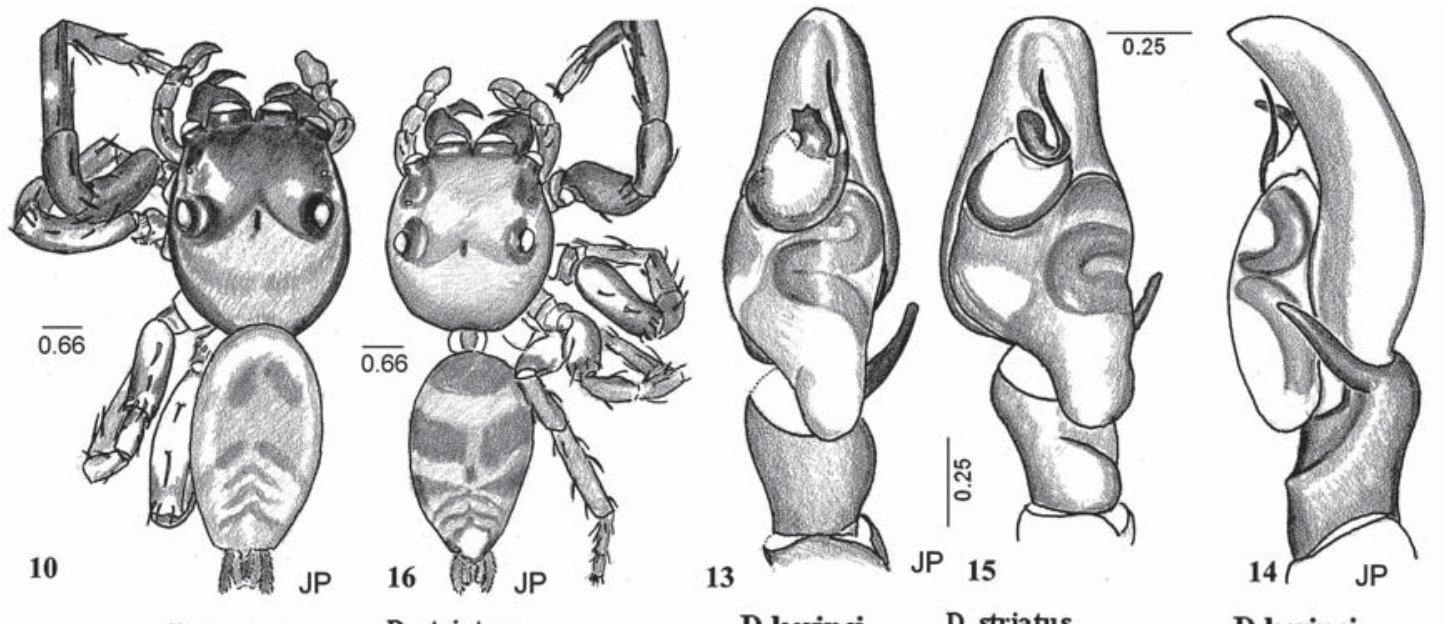

D. kerinci

D. striatus

D. kerinci

D. striatus

D. kerinci

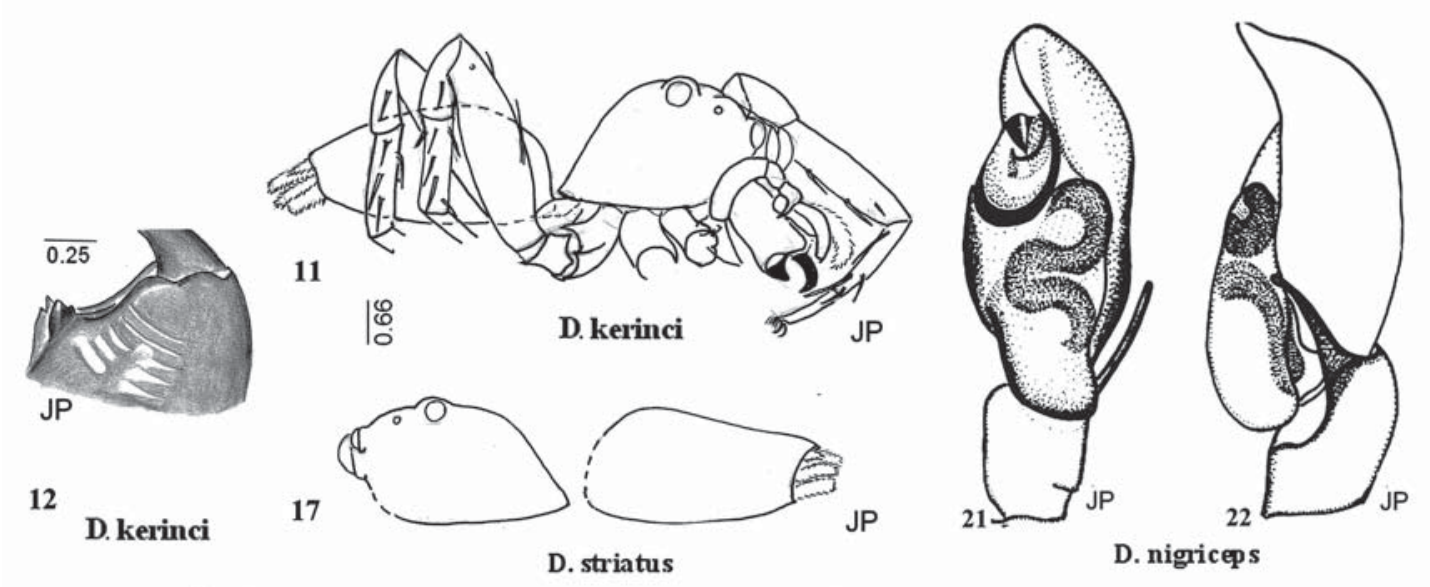

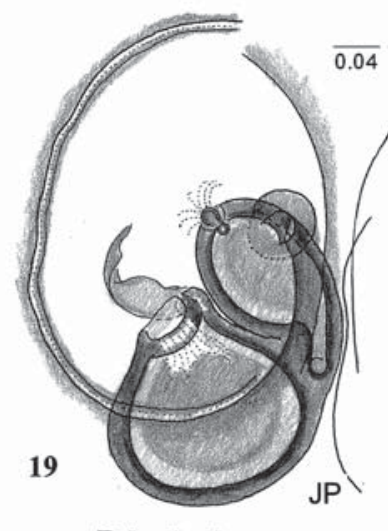

D. kerinci

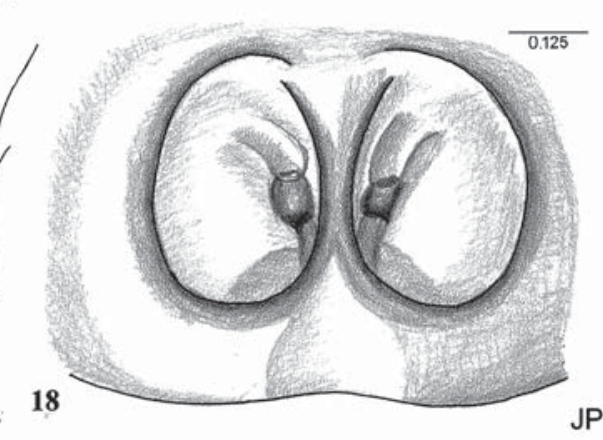

D. kerinci

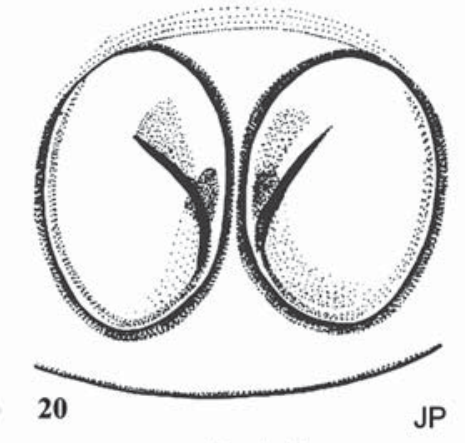

D. nigriceps

Figs 10-22. General appearance and copulatory organs of Donoessus kerinci sp.n. (10-14, 18-19), D. striatus from Borneo: Sabah (15-17) and D. nigriceps from Mentavei Is. (20-22): 10, 16 - general appearance, dorsal view; 11, 17 - general appearance, lateral view; 12 - cheliceral tooth; $13-14,21-22$ - palpus, ventral and lateral view; 18-20 - epigyne: ventral view and internal structures. 1014, 18-19 - from Sumatra: Kerinci; 15-17 — from Borneo: Sabah; 20-22 - from Mentavei. 20-22 — after Prószyński [1984b].

Рис. 10-22. Внешний вид и копулятивные органы Donoessus kerinci sp.n. (10-14, 18-19), D. striatus (15-17) и D. nigriceps из ова Ментавеи (20-22): 10, 16 - внешний вид, дорзально; 11, 17 - внешний вид, сбоку; 12 - зубец хелицеры; 13-14, 21-22 пальпа, снизу и сбоку; $18-20$ - эпигина: снизу и внутреннее строение. $10-14,18-19$ - из Суматры: Керинчи; $15-17$ — из Борнео: Сабах. 20-22 — по Prószyński [1984b]. 
D. s.: Żabka, 1988: 451, f. 84-86 (or)

MATERIAL. 1 T', Borneo: E Sabah, Danum Valley Field Centre, lowland primary forest, 6-16 May, 1991. Leg. C.L. Deeleman. CDML.

Photograph labelled as $q$ Donoessus nigriceps 1 Borneo: Sabah, Danum Valley (910), primary lowland forest. 15 April, 2003. CPhoto by P. Koomen [in Prószyński, 2011].

DIAGNOSIS. Male differs from D. kerinci sp.n. from Sumatra by having inclined white and black bars on the abdomen (Fig. 16). Palpus resembles that of $D$. kerinci sp.n. but the bulbus is broader (Fig. 15).

DESCRIPTION. Male. General appearance resembling female photographed by P. Koomen (reproduced in Prószyński [2011]). Carapace oval, broader than abdomen. Measurements: length of carapace 3.0, width 2.64 , height of carapace 2.0, length of eyefield 1.90, length of abdomen 3.3, width of abdomen 1.98 .

Female (description made from two photographs of a single specimen, photographed alive and then again after several years of preservation, identification and conspecificity uncertain). Preserved specimen somewhat discoloured, with black areas of body appearing brown. Carapace broad, medium high, eyefield rectangular, broader than long, with a pair of minute white spots at eyes II. There is semilunar white bar just behind the eyefield, expanded diamond-like in the foveal region. Sides brown. Eyes I median twice the size as I lateral, all aligned along their dorsal rims, surrounded by thin line of short white setae, there is thin band of white setae above eyes medial. Clypeus dark brown with very thin line of short white setae along ventral edge. Chelicerae robust, brown, with bifid (fissidentate) tooth on inner edge. Pedipalpi light. Legs I the longest, discolored to yellow with brownish lateral surfaces, with indistinct spots of white setae on tibia and femur. Two pairs of ventral spines on metatarsi I-II, distinctly longer than spines on tibia. Legs III-IV lighter than I and II. Abdomen indistinctly narrower than carapace, oval. Dark brown with two light transversal bars on anterior edge and in the mid-length of abdomen. Posterior end of abdomen light, with dark, indistinct small spots. Fresh specimen differs from the preserved one by contrasting pattern of almost black body, with striking white spots on carapace and abdomen, legs light brown with indistinct white spots basally on tibiae I-IV and apically on femora I-IV.

Epigyne oval, divided incompletely into two membranous "windows", with sclerotized edge, copulatory opening at the medial part of edge, in about $1 / 3^{\text {rd }}$ length of epigyne.

DISTRIBUTION. Documented from Borneo Island.

Genus Emathis Simon, 1899

Type species Emathis weyersi Simon, 1899, from Sumatra and Borneo.

REMARKS. The generic name Emathis should be restricted to the four South East Asian species, and to their unnamed relatives. They resemble the type species $E$. weyersi by having a large coil of the embolus in the anterior half of the bulbus in males, parallel to its surface (Fig. 30), and prominent double spirals of the copulatory ducts in females (Figs 32-33), analogous to some species in the non-Euophryinae genera: Telamonia Thorell, 1887, Marpissa C.L. Koch, 1846, or Yllenus Simon, 1868. While interpretation of genus identification is not contested, interpretation of the species E. coprea (Thorell, 1890) and E. weyersi is based on non-type specimens in the collection of Reimoser in NHM-Vienna; their type specimens are kept in MNHN in Paris and MCSN-Genoa, but have no associated figures. The structure of the epigyne of E. makilingensis Barrion \& Litsinger, 1995 (Fig. 33) is typical for the genus, but the axis of the coils is rotated by $90^{\circ}$ and vertical.

The list of Emathis species is as follows:

E. coprea (Thorell, 1890) from Indonesia: Sumatra.

E. makilingensis Barrion \& Litsinger, 1995 from Philippines: Luzon.

E. sobara (Thorell, 1890) from Indonesia: Sumatra.

E. weyersi Simon, 1899 from Sumatra, Borneo and Philippines: Luzon.

In addition, there are several undescribed species from Borneo, documented by photographs by P. Koomen [Prószyński, 2011].

The Carribean species originally described in Emathis are transferred to the genus Petemathis gen.n., see below.

\section{Emathis sumatranus sp.n.}

Figs 23-33.

MATERIAL. Holotype $\sigma^{\top}$, allotype $1 \uparrow$, Sumatra: Mt. Singalang: Anai, $460 \mathrm{~m}$, secondary forest, from leaves, 10-22 June, 1994. Leg. S. Djojosudharmo. CDML.

COMPARATIVE MATERIAL. E. makilingensis Barrion \& Litsinger, 1995: 1 + holotype Philippines: Luzon Is.: Mt. Makiling, 13 April, 1977. De Castro Coll. Los Banos. IRRI. (Fig. 29). O', 1 , Luzon, Mt. Makiling, Leg. Baker. Coll. Reimoser. NHMW.

ETYMOLOGY. Named for Sumatra Island, in Indonesia.

DIAGNOSIS. Male differs from E. weyersi (Fig. 30) by larger coil of embolus, much broader bulbus, broader and less bent tibial apophysis (Figs 27-29). Female's double spiral of copulatory ducts (Fig. 32), roughly perpendicular to the body axis, is similar to female of E. weyersi [Prószyński, 1984: 37] but has more coils, it differs from double spiral in $E$. makilingensis (Fig. 33) which is parallel to body axis and the first part of the duct is half shorter.

DESCRIPTION. Male. Body shape and proportions shown in Figs 23-24. Chelicerae with enormous tooth, very close to fang (Fig. 25). Palpus with cymbium twice as long as the tibia. Loop of embolus enormous, occupying $2 / 3$ the length of the bulbus and almost the whole width, arranged parallel to the bulbus and lying on its ventral surface (Figs 27-29).

Female. Somatic characters are not documented. Epigyne with semicircular depression and copulatory openings located in its mid-length (Fig. 31). Copulatory duct begins with a semi-arch and is continued by coils twisted into a tight double spiral, forming a com- 

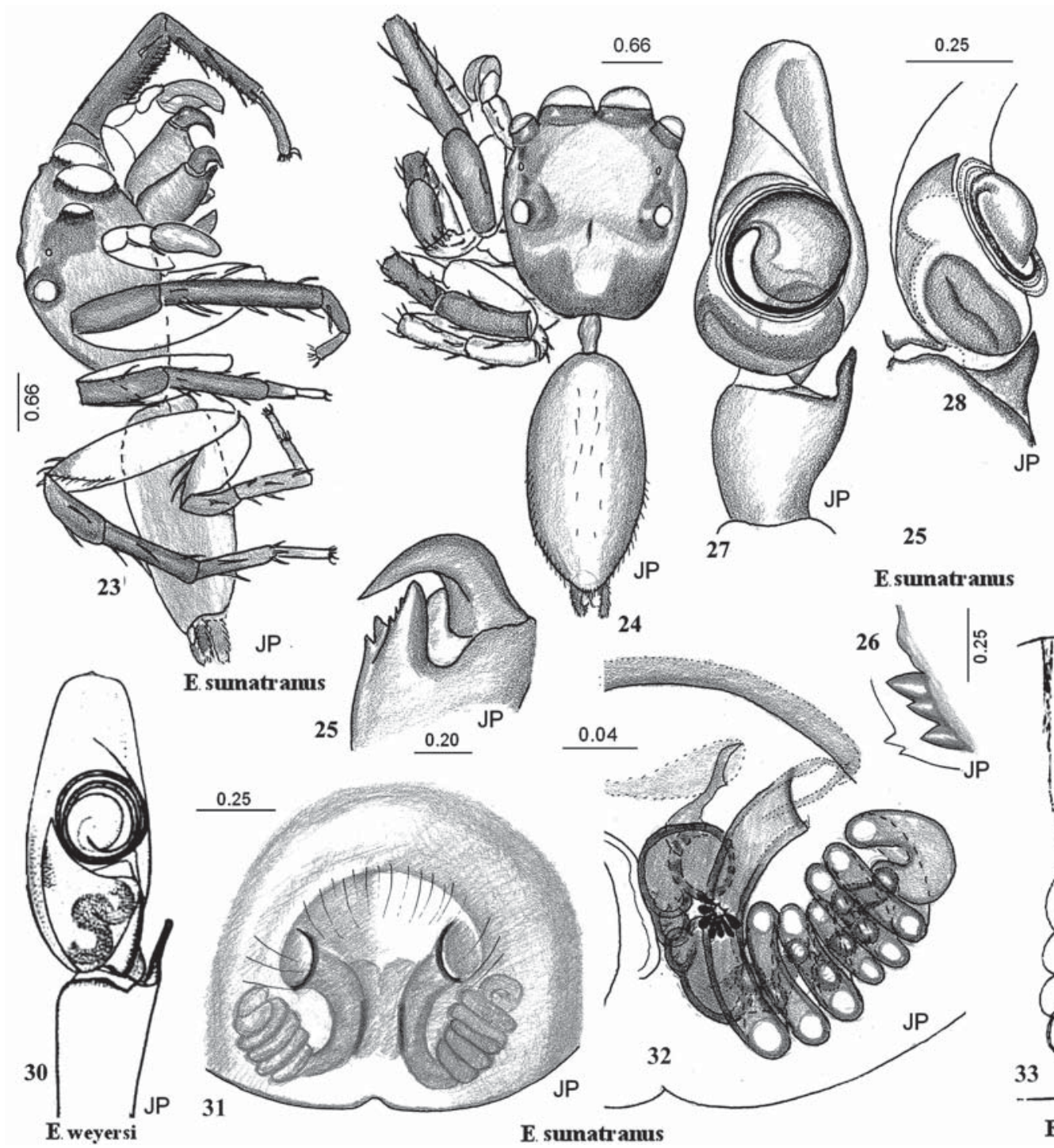

25

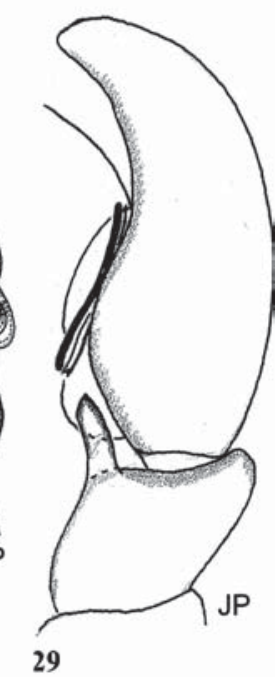

E sumatranus
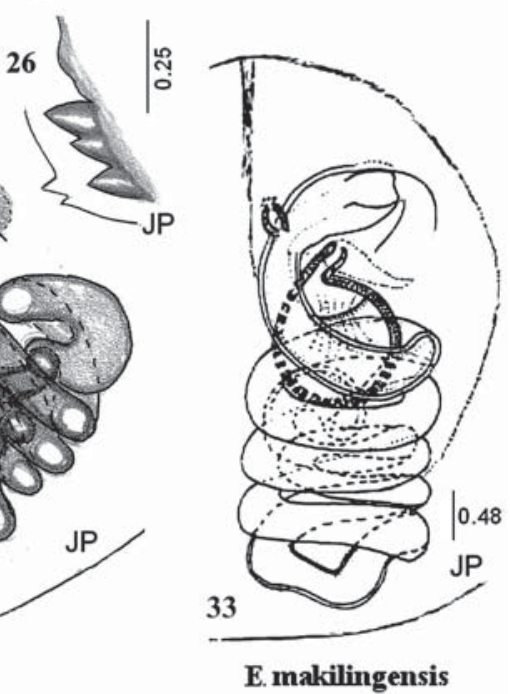

Figs 23-33. General appearance and copulatory organs of Emathis sumatranus sp.n. (23-29), E. makilingensis (33) and E. weyersi (30): 23-24 - general appearance, dorsal and lateral views; 25 - cheliceral dentition, male; 26 - cheliceral dentition. female; $27-30-$ palpus, ventral, prolatero-ventral and lateral views; 31 - epigyne; 32-33 - internal structures of epigyne. 23-29 - from Sumatra: Singalang; 30, 33 - from Philippines: Luzon Is. 30 - after Prószyński [1984b].

Рис. 23-33. Внешний вид и копулятивные органы Emathis sumatranus sp.n. (23-29), E. makilingensis (33) и E. weyersi (30): 2324 - внешний вид, дорзально и сбоку; 25 - вооружение хелицер, самец; 26 - вооружение хелицер, самка; 27-30- пальпа, снизу, пролатерально-снизу и сбоку; 31 - эпигина; 32-33 - внутреннее строение эпигины. 23-29 — из Суматры: Singalang; 30, 33 - из Филиппин: Luzon Is. 30 - по Prószyński [1984b].

pact structure arranged transversally, slightly obliquely, across the epigyne. Spermatheca located at the median end of that spiral, is small and arranged parallel to the main axis of the body (Fig. 32).

REMARKS. Photographs of uncleared epigynes of 5 specimens of Emathis sp. from Borneo: Sabah: Sukau by P. Koomen (in Prószyński [2011]) illustrate the diversity of internal structures: positions of the double spiral of the copulatory ducts vary from longitudinal to transverse. It is not clear whether these belong to different species or whether the character is variable. $E$. makilingensis has spiral ducts arranged parallel to the main body axis (Fig. 33). There are not enough data on E. coprea from Sumatra for comparison.

DISTRIBUTION. Documented from Indonesia: Sumatra.

Genus Epeus Peckham \& Peckham, 1885

Type species Evenus tener Simon, 1877 from Java.

REMARKS. This Oriental genus belonging to the subfamily Plexippinae, includes 14 species, with several undescribed species from Java, Borneo, Bali, and apparently on other islands. The external appearance 

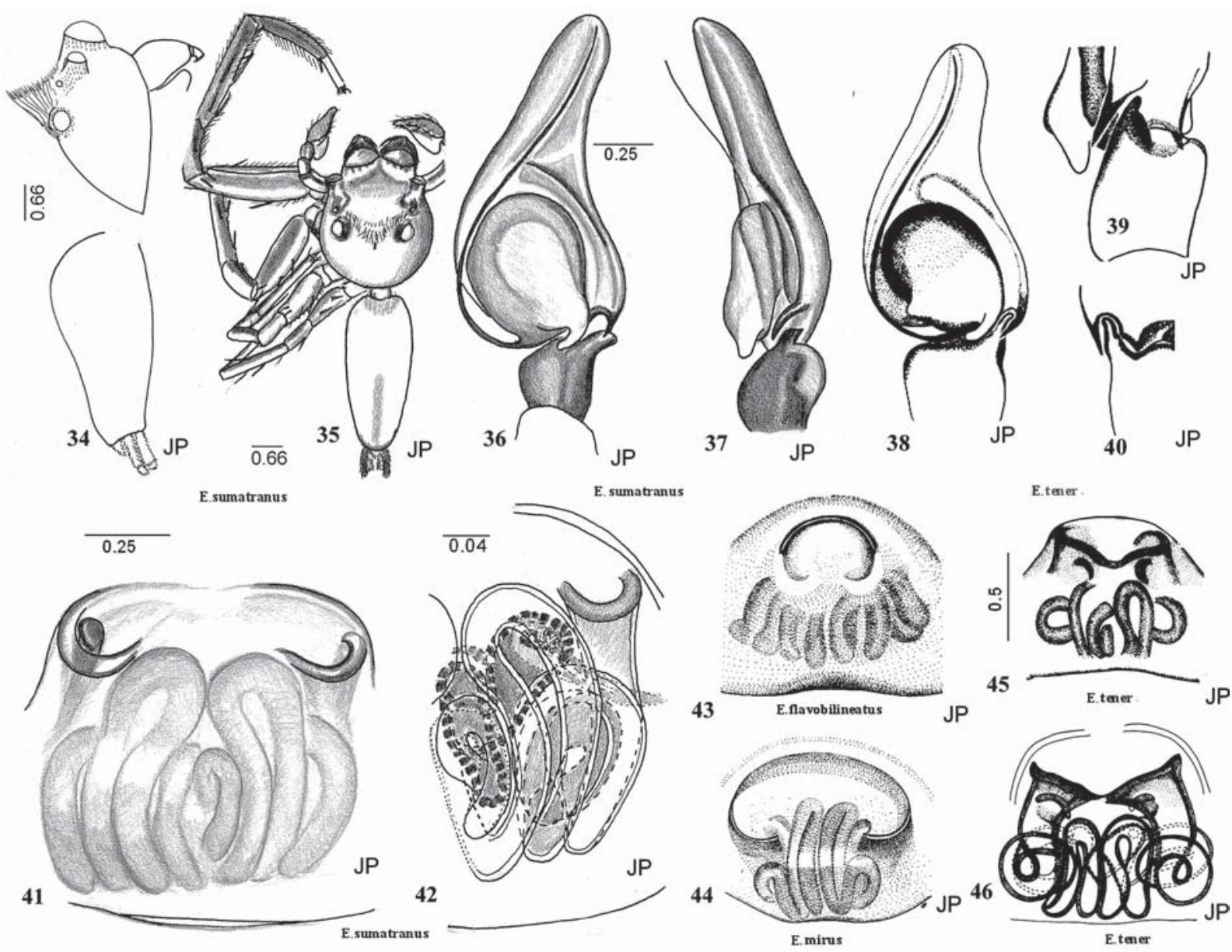

Figs 34-46. General appearance and copulatory organs of Epeus sumatranus sp.n. (34-37, 41-42), E. flavobilineatus (43), E. mirus (44), E. tener (38-40, 45-46): 34-35 - general appearance, lateral and dorsal views; 36-37 - palpus, ventral, dorsal and lateral views; 41-46 - epigyne and its internal structure. 34-37, 41-42 - Sumatra: Mt. Singalang; 38-40 — Philippines: Mindanao Is.; 43, 45-46 Java; 44 — Borneo; 39-40 — after Prószyński [1984b, 1984a]; 38-40 — after Prószyński [2011, online].

Рис. 34-46. Внешний вид и копулятивные органы Epeus sumatranus sp.n. (34-37, 41-42), E. flavobilineatus (43), E. mirus (44) и E. tener (38-40, 45-46): 34-35 - внешний вид, сбоку и дорзально; 36-37 - пальпа, снизу, дорзально и сбоку; 41-46 - эпигина и её внутреннее строение. 34-37, 41-42 - Суматра: Mt. Singalang; 38-40 - Филиппины: Mindanao Is.; 43, 45-46 - Ява; 44 Борнео; 39-40 — по Prószyński [1984a, b]; 38-40 — по Prószyński [2011].

of males is remarkable, resulting from a prominent conical comb of upright setae on the posterior half of the eyefield (Figs 34-35), arising from a semicircular base (absent in females!). Cymbium broadened posteriorly, with the posterior retrolateral tip drawn out into a pointed process, narrow and long, articulating with the tibial apophysis. Coloration of several females from various localities is rather similar, with two yellow abdominal streaks on a green background. Living specimens of Epeus tend to be light green, with variously coloured palpi and legs. There are problems with species interpretation of E. flavobilineatus (Doleschall, 1859), due to the absence of the type specimen (see Prószyński \& Deeleman-Reinhold [2010: 165]). The epigyne of Epeus has an anterior oval depression and copulatory ducts with numerous coils, translucent through the tegument.

There is some similarity between Epeus and Plexippoides Prószyński, 1976 (containing 22 species) which has a comparable sharp cymbial process, the cymbium itself being broader and shorter. The structure of the epigyne in Plexippoides is different, but a species from Nepal (P. tristis Próchniewicz, 1990) has an epigyne intermediate between the two genera as currently defined. Thus, the relationships between these genera deserve some attention.

According to a photograph by Knowles (in Prószyński [2011]), females of Epeus sp. in Bali (E. flavobilineatus?) guard a brood of 40 light green eggs deposited on a leaf, additionally protected from above by several stretched silk threads.

\section{Epeus sumatranus sp.n.}

Figs 34-46.

MATERIAL. Holotype + , allotype $\sigma^{\top}$, paratypes $4 \sigma^{\top} \sigma^{\top}, 8$ o 8 , Epeus sp 1. Sumatra: Mt. Singalang, 440-460 m, secondary forest, from leaves, 10-22 June, 1994. Leg. S. Djojosudharmo. CDML. 
COMPARATIVE MATERIAL of Epeus (labels quoted with original name combinations). 1 V Viciria flavobilineata . Java: Kagok. Coll. W. Kulczyñski. MiIZ. O’o “20345 Vic. tenera ES. Java: Palab. Tenger/Tr." Coll Simon. MNHN. "Taupoa mira Peckh. Borneo, 3214, Shelford C.W. and E.G. Peckham”. MCZ.

ETYMOLOGY. Named for Sumatra Island, in Indonesia.

DIAGNOSIS. Tip of cymbium narrower than in $E$. tener (Figs 38-40) and distinctly inclined (Figs 3637). Female differs from E. flavobilineatus and E. mirus (Peckham et Peckham, 1907) (Figs 43-44) by their narrower anterior depression of the epigyne (Figs 41), from E. tener (Figs 45-46) by the loops of the copulatory ducts being distinctly shorter than the copulatory ducts (Fig. 42).

DESCRIPTION. Male. Carapace broad, posteriorly semicircular, moderately high, eyefield extends over half of carapace, thoracic region gently sloping, without a horizontal region (Figs 34-35). Characteristic comb of setae arising semicircularly on eyefield well developed. Coloration of body not preserved, Abdomen oval, longer by $1 / 5$ than carapace, narrower than carapace and narrowing posteriorly. Palpus characteristic by having retrolateral angle of cymbium long and pointed, touching tip of tibial apophysis. Anterior tip of cymbium elongated and narrow, inclined laterally at an angle of about $45^{\circ}$ (Fig. 36). Bulbus broad, half encircled by a long, hair-like embolus.

Female. Abdomen elongated oval, green with two broad yellow marginal streaks, merged posteriorly. Copulatory openings located at the sides of a narrow, transverse depression (Fig. 41), located level with the top of the coils of the translucent copulatory ducts. These coils form a short double spiral, with a transversally oriented axis, consisting of 4 loops (Fig. 42).

REMARK. The female is designated as the holotype because in this genus specific differences in the epigyne are more noticeable (Figs 41-46) than those in the palpi of males.

DISTRIBUTION. Documented from Indonesia: Sumatra.

\section{Genus Gelotia Thorell, 1890}

Type species Gelotia frenata Thorell, 1890 from Sumatra.

REMARKS. A genus of the subfamily Spartaeinae consisting of 8 nominal species, occurring mainly in countries of the Malay Archipelago. They are relatively well known owing to the studies by Wanless [1984]. Comparison of the Malay Archipelago species is hampered by knowledge of only one sex in particular species. There is confusion resulting from Wanless [1984: 172-174, f. 17A-J] matching a male of G. bouchardi (Simon, 1903) from Sumatra with a female of $G$. bimaculata Thorell, 1890 from Borneo, especially as it is unclear whether his drawing of the male depicts a Sumatran or Bornean specimen. Pending revision of fresh specimens from both islands, we assume that these species are separate and hypothesize that the specimens described below represent $G$. bouchardi.

\section{Gelotia bouchardi (Simon, 1903)}

Figs 47-58.

Codeta b. Simon, 1903b: $305\left(\sigma^{7}\right)$.

G. bimaculata: Wanless, 1984: 172 ( $\sigma^{7}$ only, assumed synonymy)

MATERIAL. $1 \sigma^{7}, 1$, Sumatra: Gunung Leuser National Park at Bohorok A, riverside, 28 September, 1983. Leg. S. Djojosudharmo. CDML.

COMPARATIVE MATERIAL. Gelotia bimaculata: Sabah: Trus Madi, 824. Photo (C P. Koomen [Prószyński, 2011].

DIAGNOSIS. Female differs from $G$. bimaculata (Figs 53-54), by the epigyne narrowing posteriorly, and in its internal structures, see also $G$. frenata Thorell, 1890 (Fig. 55). Male differs from G. argenteolimbata (Simon, 1900) from Singapore by the length and shape of the embolus and the tibial apophysis (Figs 56-58), see also Wanless [1984: f. 17D].

DESCRIPTION. Male. Somatic characters are not documented. Palpus with distinct semilunar flattening of the retrolateral surface of the cymbium. Retrolateral tibial apophysis viewed laterally is thin and bent, in ventral view is basally expanded into a small plate. Dorsally, palpal tibia is covered by dense white setae (Figs 49-50), prominently visible also on photographs of related species from Borneo [Prószyński, 2011].

Female. Measurements (in mm, approximate): length of carapace 3.7 , length of abdomen 3.8 , length of eyefield 1.6, width of eyefield I 2.20, width of eyefield III 2.0 , height of eyefield 1.8. Body shape and proportions are shown in Figs 47-48. Posterior half of epigyne narrowing (Fig. 51), with posterior sclerotized fold and raised median septum. Copulatory openings anterior median, located on small sclerotized protuberance. Superficial narrowing of epigyne does not influence shape of spermathecae, which are broad oval and long, their internal surface covered with minute teeth (Fig. 52).

DISTRIBUTION. Documented from Indonesia: Sumatra.

\section{Genus Heratemita Strand, 1932}

Type species Heratemita chrysozona (Simon, 1899).

REMARKS. This genus was described by Simon 1899 as Heratemis Simon, 1899 (name preoccupied, renamed by Strand [1932]). The genus belongs to the subfamily Simaethinae and contains, apart from the type species, only one other species - H. alboplagiata (Simon, 1989) from the Philippines. It is recognizable by the particularly large white scales, dorsally on the tibia and cymbium of the palpus in males (Fig. 61). The body shape and genital organs bear some resemblance to Flacillula minuta (Berland, 1929) from the Pacific Islands [Berry et al., 1997: 125-126, f. 66-68, 71-74]. The taxonomic documentation of this genus is insufficient, Simon [1903] provided a drawing of only the cheliceral dentition, showing a peculiar inner posterior tooth: pillar-like, with a forked tip. Drawings of the genital organs of both species were published by Prószyński [1987: 41-42, 47]. However, in Simaethinae, the genital organs provide characters of limited 


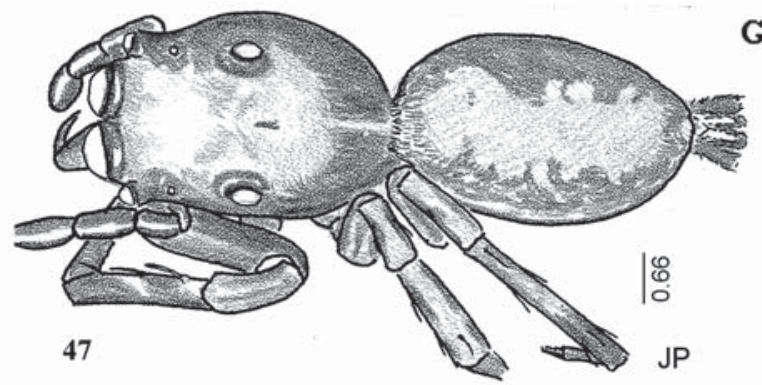

\section{G. bouchardi}

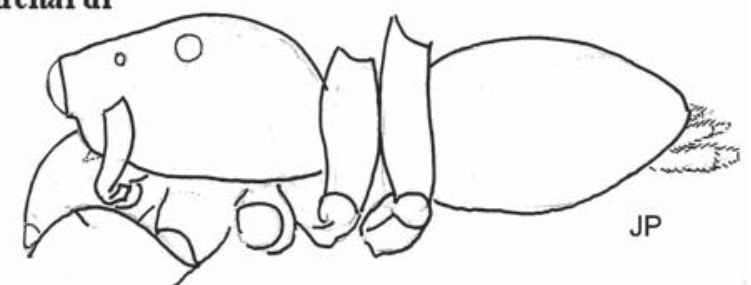

48
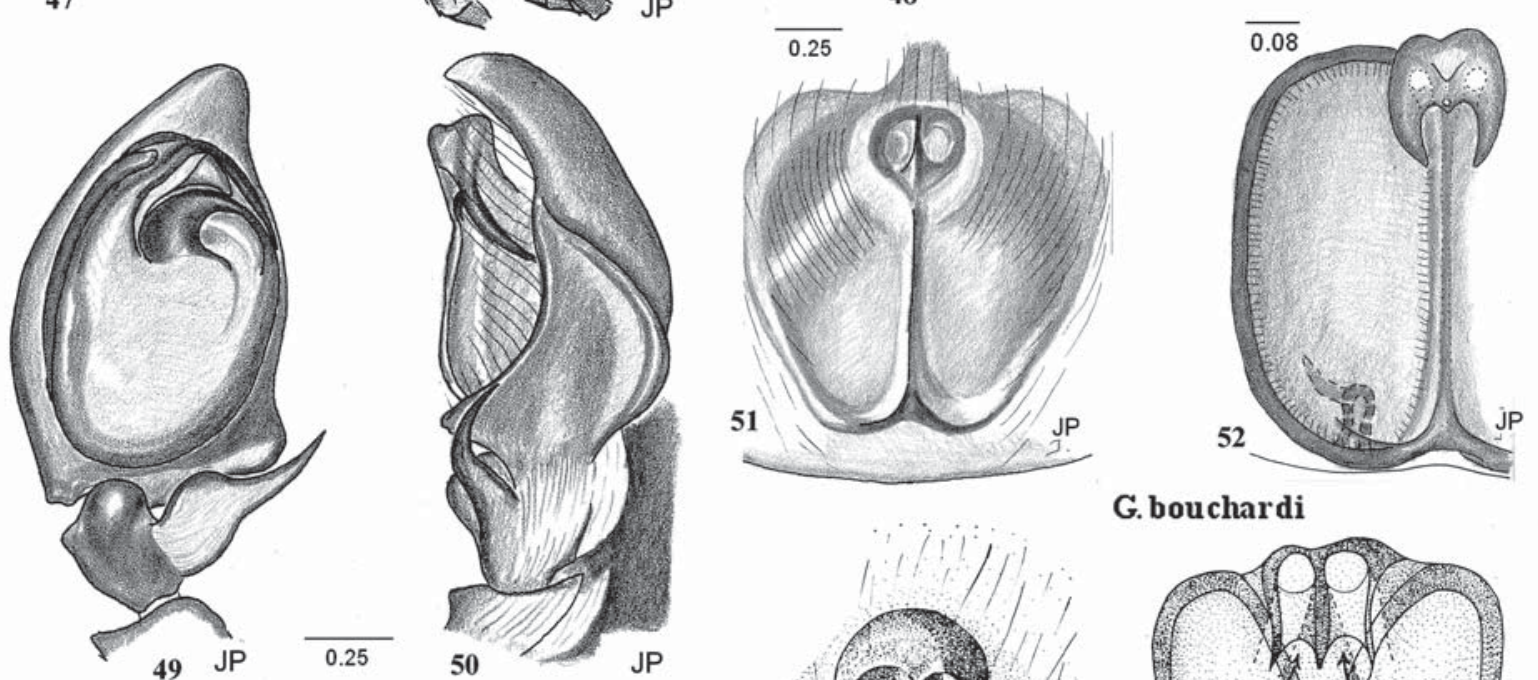

G. bouchardi

G. bouchardi
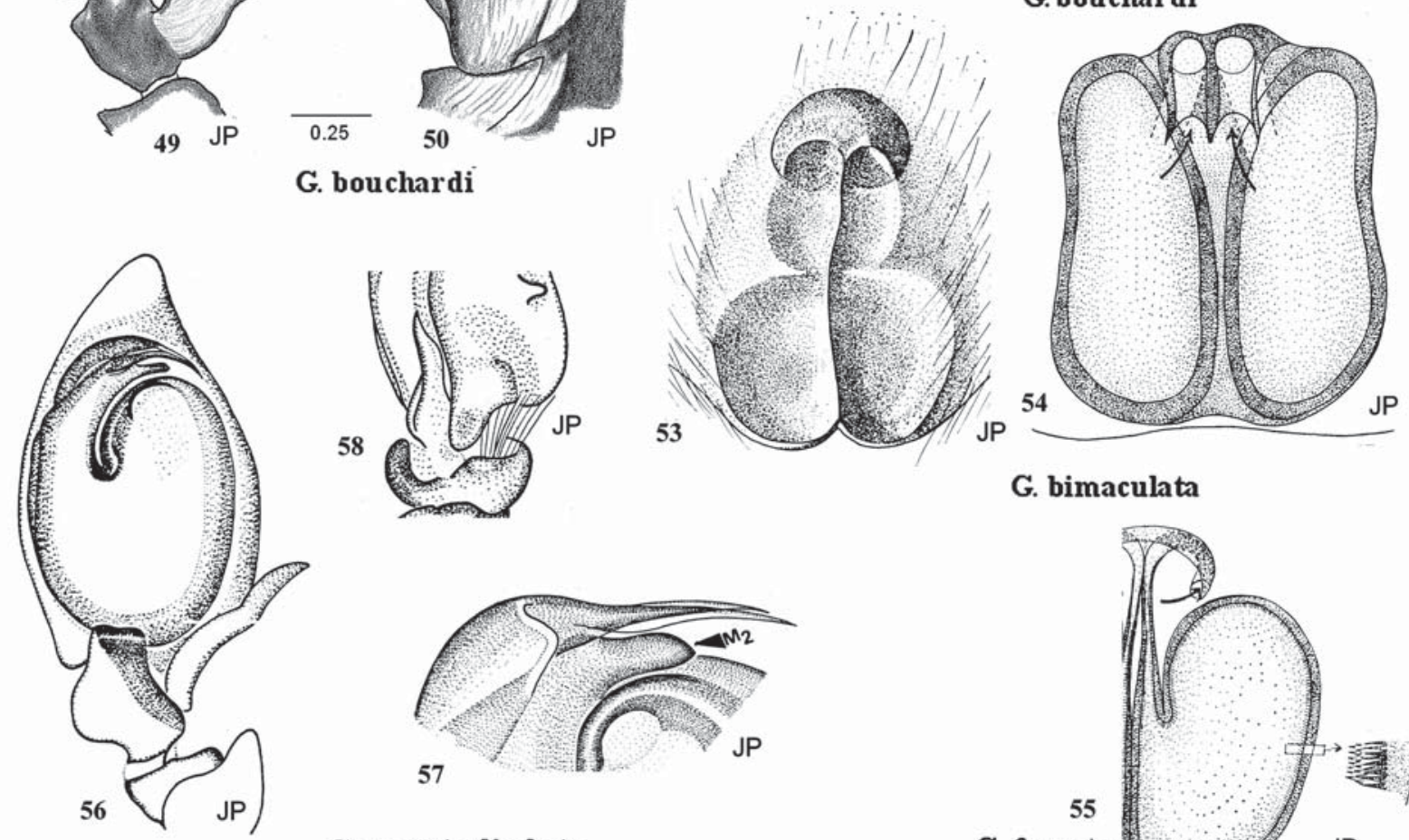

G. bimaculata
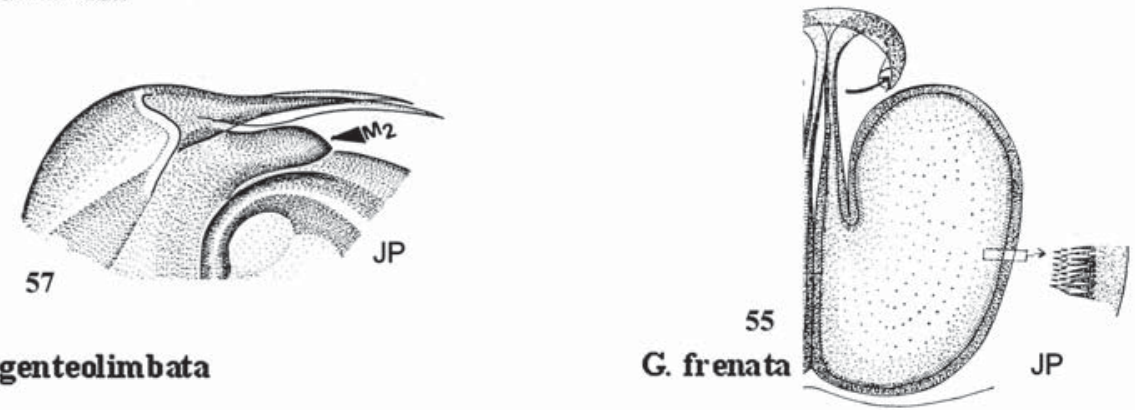

G. argenteolimbata

Figs 47-58. General appearance and copulatory organs of Gelotia argenteolimbata (56-58), G. bimaculata (53-54), G. bouchardi (47-52), and G. frenata (55): 47-48 - general appearance, dorsal and lateral views; 49-50, 56-57 — palpus, ventral and lateral views; 51-55 - epigyne and its internal structures. 47-52, 55 - from Sumatra; 56-58 - from Singapore, 53-54 - from Borneo. 53-55 - after Prószyński [1968a]; 56-57 — after Prószyński [1987].

Рис. 47-58. Внешний вид и копулятивные органы Gelotia argenteolimbata (56-58), G. bimaculata (53-54), G. bouchardi (47-52) и G. frenata (55): 47-48 - внешний вид, дорзально и сбоку; 49-50, 56-57 - пальпа, снизу и сбоку; 51-55 - эпигина и её внутреннее строение. 47-52, 55 - из Суматры; 56-58 — из Сингапура, 53-54 — из Борнео. 53-55 — по Prószyński [1968a]; 5657 - по Prószyński [1987]. 
value, and iridescent scales occur among many species in this subfamily.

\section{Heratemita tenenbaumi sp.n.}

Figs 59-65.

MATERIAL. $\bigcirc^{7}$ holotype, +9 allotype, East Sumatra, Bohorok, the sink, under leaves, 30.V.1983. Leg. S. Djojosudharmo. CDML.

ETYMOLOGY. Named after Szymon Tenenbaum (1892-1941), a prominent Polish-Jewish entomologist and teacher, who died of exhaustion in Warsaw Ghetto after refusing the chance to escape. His huge collection of beetles survived and was later deposited in the Museum of Zoology in Warsaw.

DIAGNOSIS. Differs from $H$. chrysozona by a shorter abdomen, flattened and covered with a scutum, and a thinner embolus and broader tibial apophysis in the palpus of males.

DESCRIPTION. Male. Carapace short, broad and relatively high, with eyefield extending over the majority of dorsal surface, posterior thoracic slope is steep and begins just behind eyes III (Fig. 59). Abdomen dorsally covered by dark scutum. Legs I dark, with spot of white setae on patella. Chelicera apically broad, with long pillar-shaped tooth, apically forked (Fig. 63). Cymbium covered dorsally with large white scales, covering also apical half of tibia (Fig. 61). Tibial apophysis as long as half of tibia, basally broad and gradually narrowing, articulating with lateral surface of cymbium, the small protuberance on which presumably limits articulation (Fig. 62). Palpal organ: bulbus oval, with base of embolus extending diagonally over width of bulbus. Embolus short, needle-like, arising latero-apically and extending indistinctly in front of bulbus (Fig. 60).

Female. Somatic characters are not documented. Epigyne broad and short (Fig. 64), with large median pocket in the anterior region, atop of broad, apically rounded furrow depression. There is a pair of round grooves on sides of the depression, with darkened posteromedian edge of groove, corresponding with the internal, short and bent, narrow copulatory duct. Copulatory duct is very small, located posteriorly, visible only on preparation (Fig. 65). Copulatory duct leads to large spermathecal chamber, as high as epigyne, with a small puncture in the anterior wall, followed by minute lighter area inside chamber. Second spermathecal chamber is round, half the size of the first one, with an indistinct fertilization duct attached.

DISTRIBUTION. Documented from Indonesia: Sumatra.

\section{Genus Junxattus gen.n.}

ETYMOLOGY. An arbitrary combination of letters, connected with the traditional salticid name "attus", grammatical gender - masculine.

DIAGNOSIS. Palpus of males comparable with Laufeia Simon, 1889 (Fig. 114), but differs by a very narrow, unsclerotized slit on the tegulum (Fig. 67) and the absence of a robust triangular conductor (Fig 115).
It differs from Orcevia Thorell, 1890 (Figs 108-109) by the narrowness of the bulbus and the short, slender tibial apophysis. Epigyne (Fig. 69) differs from Orcevia (Fig 113) by its simple, globular spermatheca.

DESCRIPTION. A monotypic genus of Euophryinae. Body of male is shown in Fig. 66, Carapace high, with posterior wall of thorax abrupt, almost vertical. Abdomen narrower than carapace, oval, flattened, covered by scutum. Legs relatively short, moderately robust. Palpus with narrow cymbium, not broader than tibia. Bulbus with prominent meanderig spermophor as broad as tibia, tibial apophysis short (Figs 67-68).

Somatic characters of female are not documented. Epigyne is relatively simple: triangular depression with a pair of small, oval copulatory openings located anteriorly (Fig. 70). Copulatory ducts thick-walled and short, spermatheca globular (Fig. 69).

See also description of the type species below.

REMARKS. Relationships with other genera are unclear, owing to insufficient data. In the comparable genus Laufeia the internal structures of the epigyne are unknown and the body of the male has not been illustrated.

\section{Junxattus daiqini sp.n.}

Figs 66-70.

MATERIAL. Holotype $\sigma^{\top}$, allotype + , Sumatra: Bohorok, sweeping and beating bushes, 16 June, 1983. Coll., Leg. Deeleman. CDML.

ETYMOLOGY. Named for Daiqin Li - prominent arachnologist from Singapore, author and coauthor of valuable papers on taxonomy and behavior of Salticidae.

DIAGNOSIS. See diagnosis of the genus (above).

DESCRIPTION. Male. Carapace 1.6 long, high, highest at eyes III, eye field narrowing posteriorly, slightly inclined anteriorly, with highest part at eyes III. Anterior part of the thoracic region about as long as eyefield, flat, dorsally lighter, its posterior part dark, sloping abruptly, almost vertical (Fig. 66). There is a lighter line below the lateral eyes. Abdomen near rectangular, with rounded corners and flattened, sclerotized surface, about 1.5 long and 1.0 wide. Present coloration light, with remnants of darker median streak, posteriorly with two thin reverse chevron marks. Legs short and relatively robust, leg I indistinctly longer, with darker femur and tibia, patella I with lighter median edge, metatarsus and tarsus light.

Palpal organ with narrow bulbus, tegulum split into two sclerotized plates, separated by a very narrow, slitlike space. Embolus short, forming half a loop, originating from short, triangular base atop tegulum. Posterior end of bulbus narrow and bent, sperm duct meandering, with posterior loop broader, passing into narrow ejaculatory duct running to the base of the embolus (Fig. 67). Tibial apophysis slightly inclined, terminated by small dilated plate (Fig. 68).

Female. Somatic characters not documented. Epigyne with a pair of oval grooves of copulatory openings, located in the triangular depressed area (Fig. 70). Cop- 

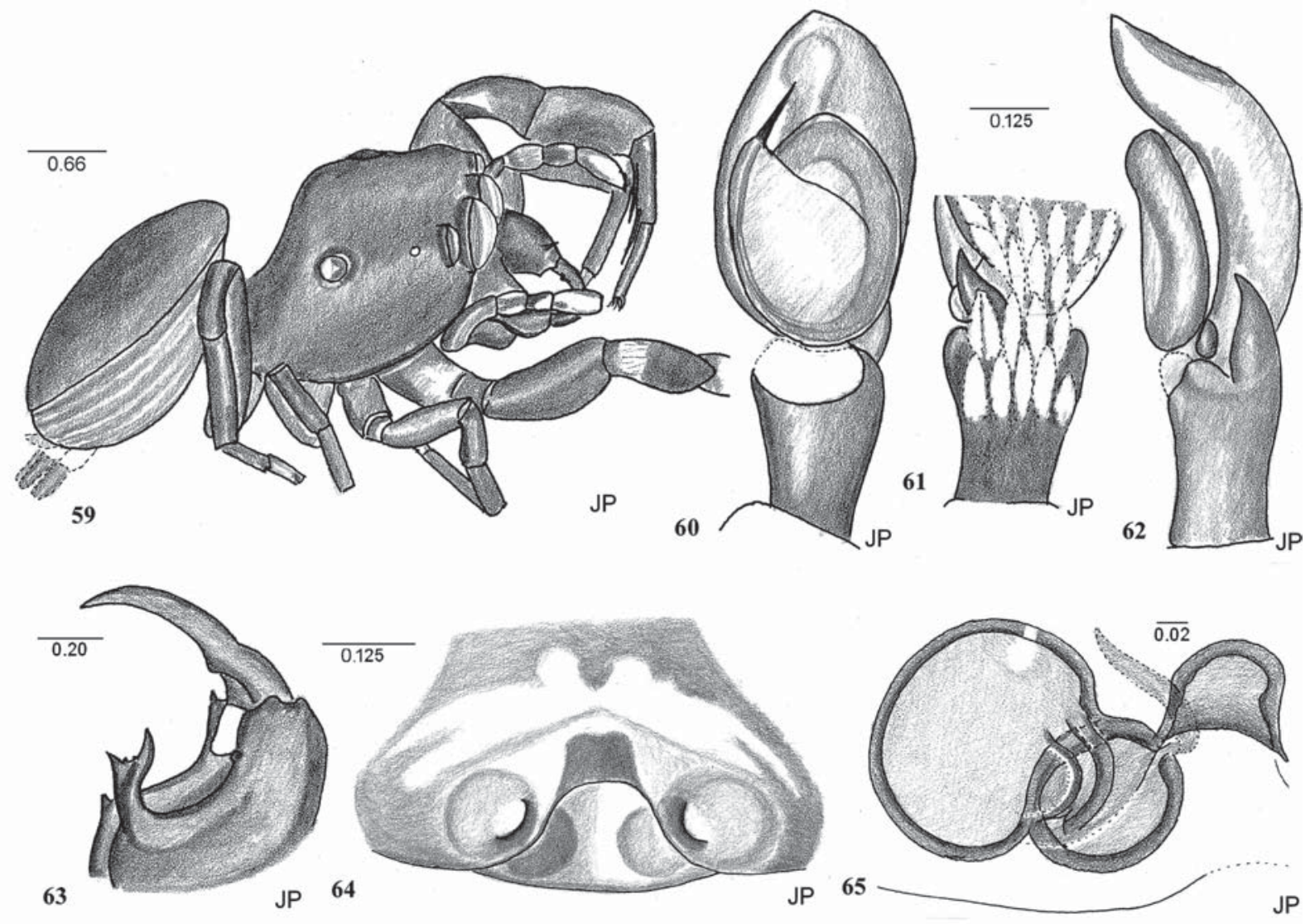

Figs 59-65. General appearance and copulatory organs of Heratemita tenenbaumi sp.n.: 59 - general appearance, latero-dorsal view; 60-62 - palpus, ventral, dorsal and lateral views; 63 - cheliceral dentition and fang; 64-65 - epigyne and its internal structures.

Рис. 59-65. Внешний вид и копулятивные органы Heratemita tenenbaumi sp.n.: 59 - внешний вид, сбоку-сверху; 60-62 пальпа, снизу, дорзально и сбоку; 63 - вооружение хелицеры; 64-65 - эпигина и её внутреннее строение.

ulatory ducts thick-walled, running almost parallel from anterior, elliptical grooves, gradually diverging sideways and joining globular, single spermathecae. Opening of scent gland piercing spermathecal wall near junction with ducts, nutritive pores in a small depression of the wall, close to the origin of the fertilization duct (Fig. 69).

DISTRIBUTION. Documented from Indonesia: Sumatra: Bohorok.

\section{Leikung porosa (Wanless, 1978)}

Figs $71-77$.

Marengo $p$. Wanless, 1978: 268, f. 7A-G; pl. 2e-f; 3a-f (P). L. p.: Benjamin, 2004: 50, f. 4D, 48A-E, 49A-D, 50A-C, 51A-F, 52A-I, 53A-F, 54A-D ( $\left(\mathrm{O}^{7}\right)$.

MATERIAL. $30^{7} \sigma^{7}, 3$ 우, Sumatra: Kerinci Seblat Nation, Park, $800 \mathrm{~m}$, near river, from leaves, 21-30 July 1988. Leg. S. Djojosudharmo. CDML.

COMPARATIVE MATERIAL. Diagnostic photo-documentation by P. Koomen displayed in Prószyński [2011] of a presumably different species from Borneo.

DIAGNOSIS. Differs from L. kinabaluensis Benjamin, 2004 by shorter palpal tibia and apophysis in males. In females the epigyne has distinctly larger coils of the copulatory ducts (Fig. 77) [Benjamin, 2004: f. 49C-D, 54].

DESCRIPTION. Male. General appearance of the body is shown in Figs 71-72, palpus shown in Figs 7475.

Female. Leg I much smaller than that of male (Fig. 73). Appearance of epigyne is shown in Fig. 76 and seems to differ from the Bohorok specimen [Benjamin, 2004: f. 50A-C] by being broader and shorter, the depression is less elongate, closer to a semicircle, posterior sclerotized edge of depression (called by Benjamin [2004] "peb") is shorter, anterior small sclerotized structure (called "aeb" and "to") is small and linear, its taxonomic value is uncertain. Course of copulatory duct, and size of spermatheca is shown in Fig. 77.

REMARKS. Benjamin [2004: 50-60, f. 48-54] was correct in calling attention to the variation in tibial apophyses and in internal epigyne structures in L. porosa from Sumatra. The course of complicated loops (Fig. 77) looks different than in the Bohorok specimen [Benjamin, 2004: f. 50B-C], in particular chambers of spermatheca are longer; these differences can be seen also on the photographs of preparations figured by 

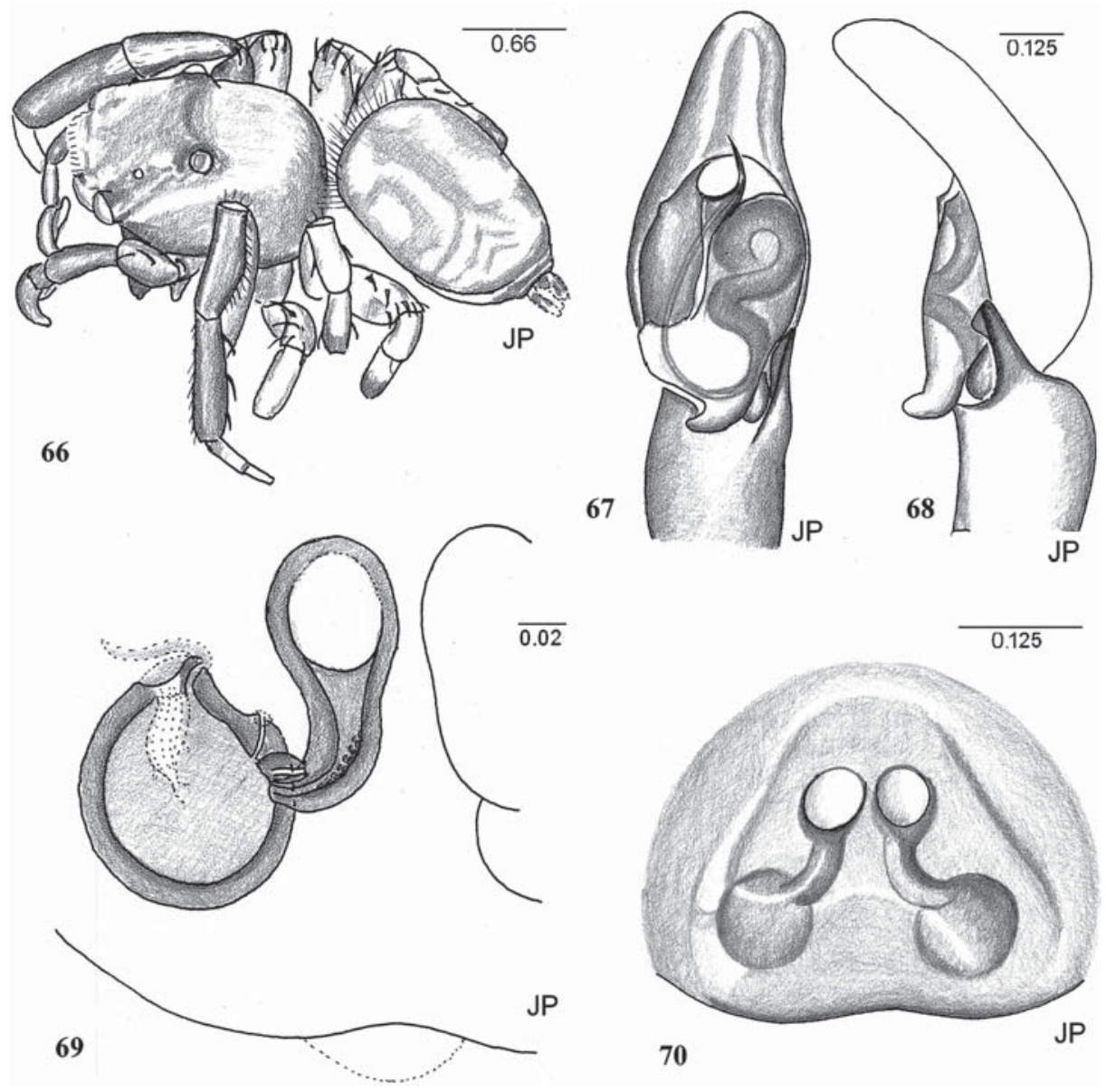

Figs 66-70. General appearance and copulatory organs of Junxattus daiqini sp.n.: 66 - general appearance, latero-dorsal view; 67-68 - palpus, ventral and lateral views; $69-70$ - epigyne and its internal structures.

Рис. 66-70. Внешний вид и копулятивные органы Junxattus daiqini sp.n.: 66 - внешний вид, сбоку-сверху; 67-68 — пальпа, снизу и сбоку; 69-70 - эпигина и её внутреннее строение.

Benjamin [2004b: f. 51A-F]. We suspect that they amount to species-specific differences.

DISTRIBUTION. Documented by us from Indonesia: Sumatra.

\section{Gen. Leuserattus gen.n.}

Type species Leuserattus gunung sp.n. from Sumatra.

REMARKS. Monotypic genus, possibly related to Euophryinae. Palpus shows some distant similarity to Phlegra gagnoa Logunov et Azarkina, 2006 from Nigeria, as illustrated by Wesołowska \& Russel-Smith [2011: f. 136-137], but the body shape and epigyne are quite different.

ETYMOLOGY. Named after the collection locality, Gunung [=mount] Leuser.

DIAGNOSIS. Genera with comparable genital structures are not known. Male recognizable by the shape of the palpus with embolus twisted into loose spring, but spermophor running around the margin of embolus (Figs 81-82), female by the epigyne with a spiral pattern of sclerotized ridges and translucent ducts (Figs 84-86).

DESCRIPTION. See description of unique species L. gunung sp.n. below. Male. Carapace broad, high, with slope of thoracic region beginning immediately behind eyefield. Abdomen elongated oval, slightly longer than crapace and narrower. Cheliceral dentition consists of three irregular cusps. Palpus with bulbus heart-shaped, with spermophor duct running along margin of bulbus (Fig. 81). Embolus forming a loose coil, tibial apohysis with short dorsal ramus.

\section{Leuserattus gunung sp.n.}

Figs 78-82.

MATERIAL. Holotype $\sigma^{7} \&$ allotype $\odot$, N Sumatra, Gunung Leuser, Bohorok, 11.VII.83. C.L. \& P.R. Deeleman. CDML.

ETYMOLOGY. Specific name derived from Indonesian word gunung "mountain" — on which was collected.

DIAGNOSIS. Epigyne resembles Saaristattus tropicus Logunov et Azarkina, 2008 by the circular pattern 


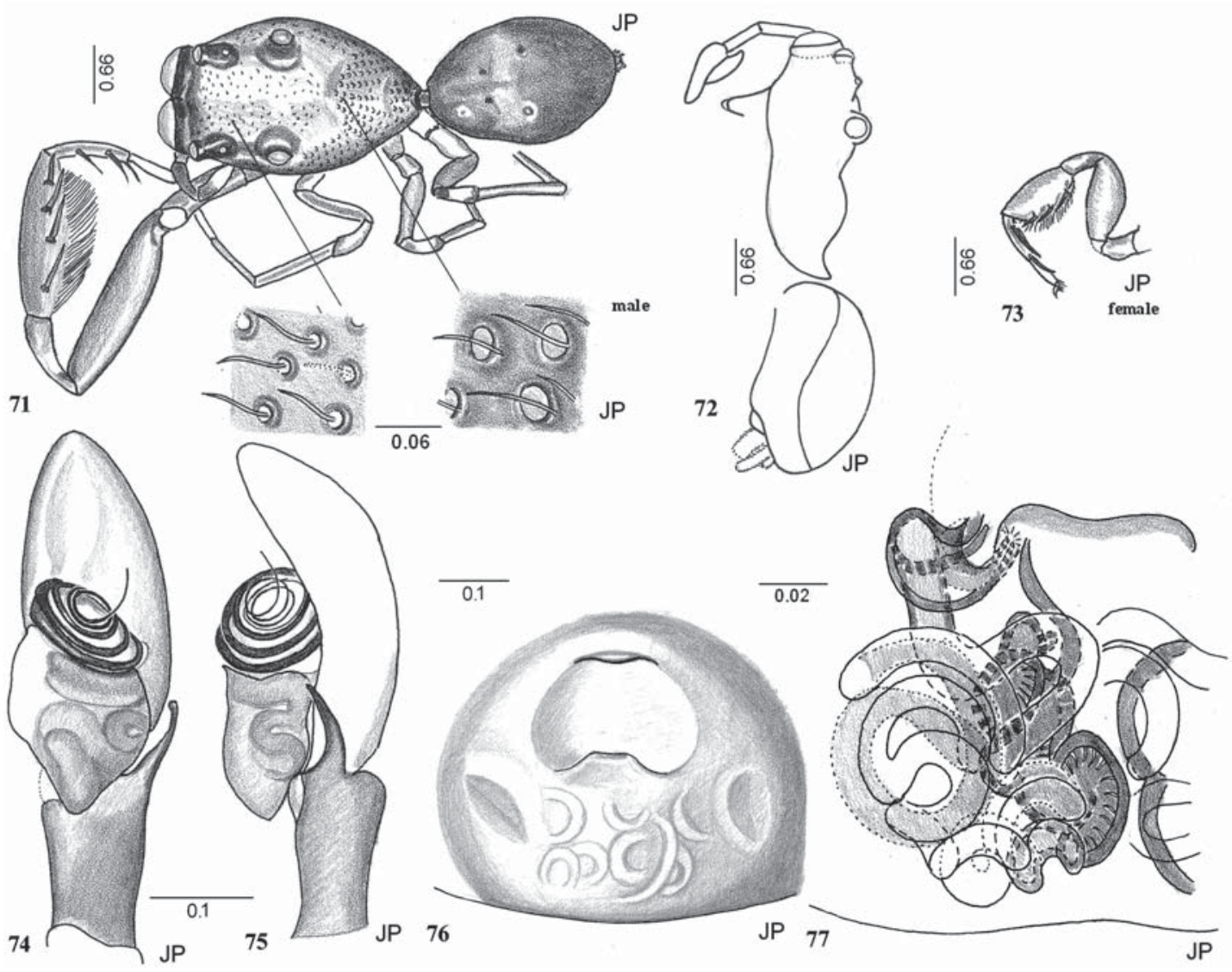

Figs 71-77. General appearance and copulatory organs of Leikung porosa: 71-72 - general appearance of male, dorsal and lateral views, with details of carapace structure; 73 - female, leg I; 74-75 - male palpus, ventral and lateral views; 76-77 — epigyne and its internal structures (note differences with species illustrated by Benjamin, 2004).

Рис. 71-77. Внешний вид и копулятивные органы Leikung porosa: 71-72 - внешний вид самца, дорзально и сбоку, показаны детали строения карапакса; 73 - самка, нога I; 74-75 - пальпа самца, снизу и сбоку; 76-77 — эпигина и её внутреннее строение.

of its translucent structures (Fig. 86). Male palp unique by the combination of a coiled embolus and a nonmeandering spermophor (Fig. 81).

DESCRIPTION. Male. Shape and proportions of the body characteristic, with carapace broad and high, abdomen oval, narrow, anteriorly higher and gradually getting lower posteriorly (Figs 78-79). Carapace 1.92 long, two times wider than abdomen, thoracic region sloping, without developed flat area (Figs 78-79). Eyefield 1.47 wide at eyes I, narrowing to 1.22 at eyes III. Abdomen elongate, oval, 1.98 long, 0.60 wide, with lighter median streak. Leg I stout, dark, with tarsus light and narrow (Fig. 83). Chelicera with single broad tooth with 3 cusps, one of which is low and indistinct (Fig. 80), there is a peculiar sclerotized, waving ridge on the posterior surface. Bulbus oval posteriorly, broadly truncated in the form of two low lobes anteriorly, spermophore without any meandering loops and courses along edge of bulbus, embolus spring-like, hair-thin, forming two loose coils (Fig. 81). Tibial apophysis forked with dorsal lobe short, triangular, sharply pointed; ventral lobe as long as tibia, slightly inclined, narrower in apical half (Fig. 82).
Female. Body shape similar to male, but abdomen as broad as carapace. Epigyne forms a light triangular depression with dark pattern of two spiral ridges and translucent ducts (Fig. 84). Internal structures of epigyne have spiral ducts convoluted in a single plane, with prominent scent gland armature, pass into spermatheca through bent, short duct, spermatheca bean-shaped, thick-walled, with prominently longer internal spines in the posterior part (Fig. 85).

DISTRIBUTION. Documented from Indonesia: Sumatra.

Mintonia tauricornis Wanless, 1984

Figs 87-95.

MATERIAL. $2 \sigma^{7} \sigma^{7}, 1$, Sumatra: Gunung Leuser National Park, Ketambe trail 12.4, buttresses, 20 February, 1985. Collector unknown. CDML.

DIAGNOSIS. Resembles M. ramipalpis (Thorell, 1890), from which it differs by having an unbranched tibial apophysis in the palpus of the male; the female has somewhat longer copulatory ducts and armature of the copulatory opening. 


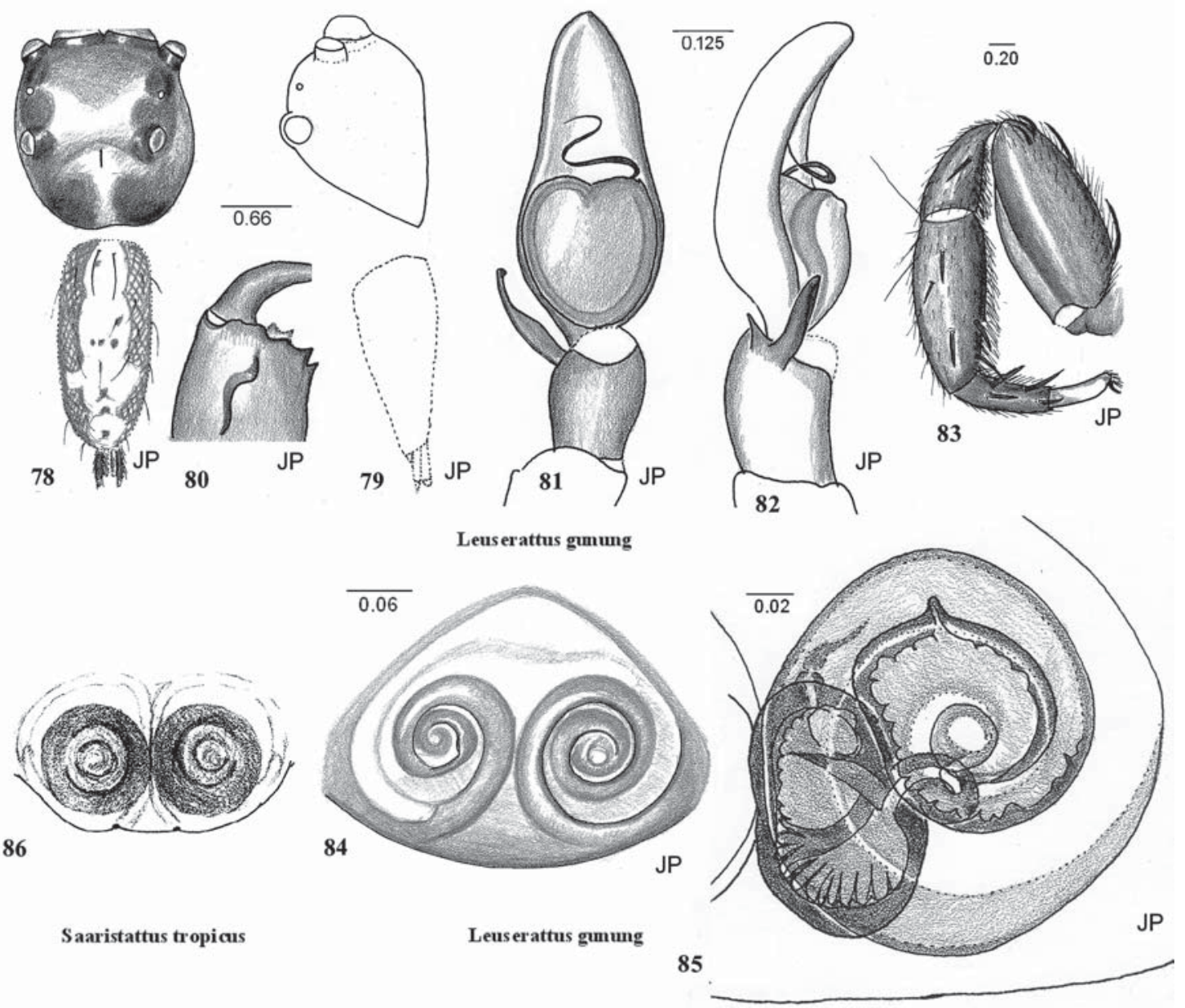

Figs 78-86. General appearance and copulatory organs of Leuserattus gunung sp.n. (78-85) and Saaristattus tropicus (86): 78-79general appearance, dorsal and lateral views; 80 - cheliceral dentition; 81-82 - palpus, ventral and lateral views; 83 - leg I; 84-86 epigyne and its internal structure. 86 - from Logunov et Azarkina, 2008.

Рис. 78-86. Внешний вид и копулятивные органы Leuserattus gunung sp.n. (78-85) и Saaristattus tropicus (86): 78-79 внешний вид, дорзально и сбоку; 80 -вооружение хелицеры; 81-82 - пальпа, снизу и сбоку; 83 - нога I; 84-86 - эпигина и её внутреннее строение. 86 - по Logunov \& Azarkina [2008].

DESCRIPTION. Male. Carapace oval, 2.2 long, 1.32 high, flat area of thoracic region 0.66 , posterior slope of thoracic region steep. Eyefield gently inclined anteriorly, its width at eyes III 1.40, indistinctly narrowing anteriorly. Abdomen elongate oval, 2.80 long, dark with broad light median spot, consisting of two diamond-like expansions, not reaching posterior end (Fig. 87). Palpus with cymbium narrow, bulbus long and oval, narrowing anteriorly, embolus anterior, set transversally, as long as cymbium width, waving and bent terminally (Fig. 89-90). There is a delicate, white structure along the embolus (Figs 91-92). Palpal tibia short and broad, with ventral anterior edge concave between tibial apophysis and ventral sclerotized notch, there is a group of white setae laterally (Fig. 89). Tibial apophysis single, long, narrow and sharply pointed, straight but inclined (Fig. 90).

Female. External appearance shown in Fig. 87. Carapace oval, 2.0 long. Eyefield indistinctly narrowing anteriorly, its width at eyes III 1.40. Abdomen elongate oval, 2.44 long, dark with broad light median spot, consisting of two diamond-like expansions, not reaching posterior end. Legs light with darker rings. Epigyne has an anterior round depression (about the size of single spermatheca) in front of translucent spermathecae, edge of depression sclerotized and bent (Fig. 93). Spermathecae globular (Figs 94-95), thick-walled, with setae-like projections on internal surface. Copulatory ducts very short, sclerotized, as thick as the rim of the copulatory openings, scent opening armature prominent, located in space between duct and spermatheca.

REMARKS. Type species of the genus. In male specimens from Borneo: Sarawak [Wanless, 1984: 158] there are minor differences in the tip of the retrolateral tibial apophysis, which is straight, although inclined diagonally, and they have a shorter embolus. The drawing technique of Wanless [1984: figs 8A, D] makes interpretation of differences in the epigyne difficult. 

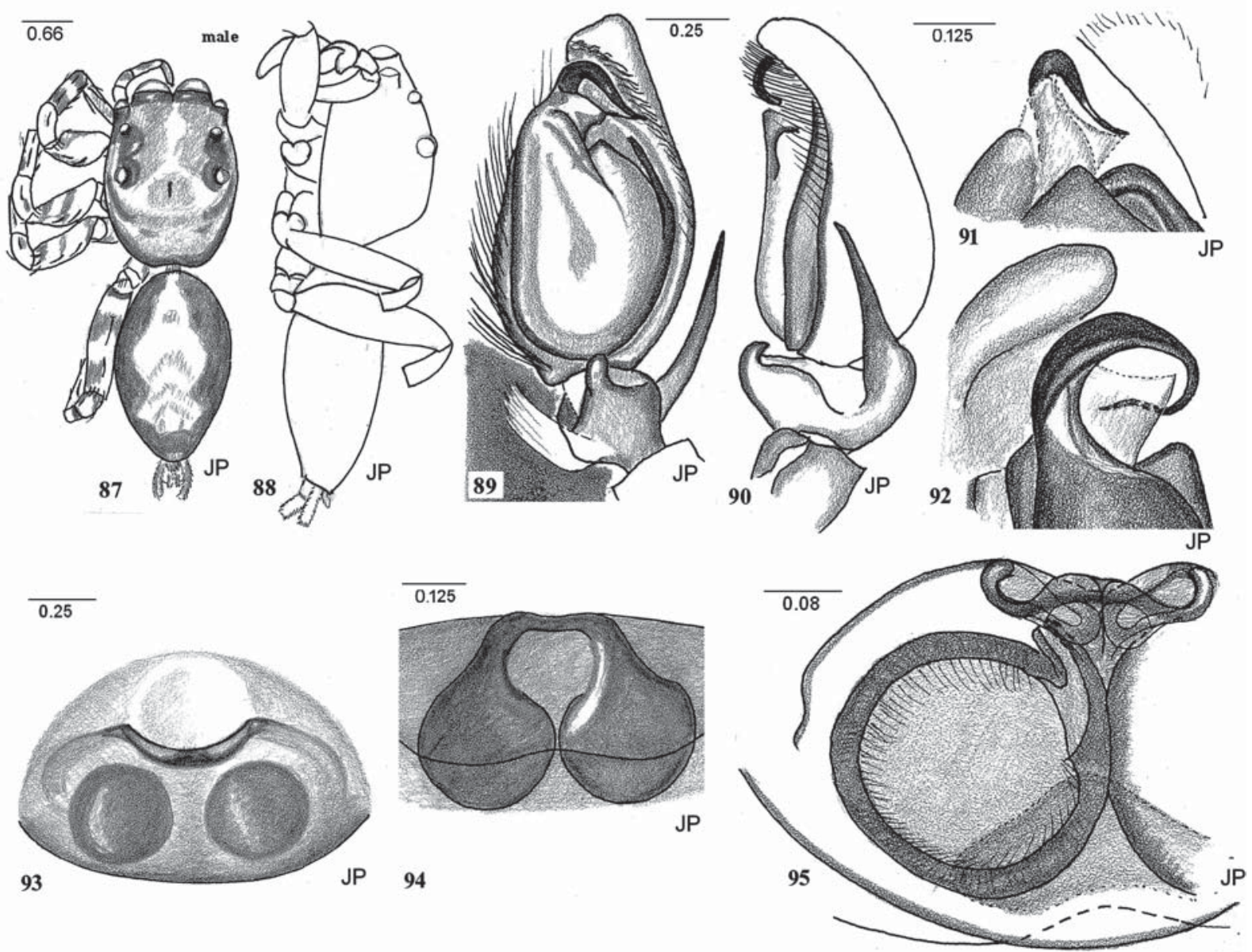

Figs 87-95. General appearance and copulatory organs of Mintonia tauricornis: 87 - general appearance of female, dorsal view; 88 - general appearance of male, lateral view; 90-92 — palpus, ventral and lateral view, and two views on rmbolus; 93-95 - epigyne, ventral and posterior view, as well as its internal structures.

Рис. 87-95. Внешний вид и копулятивные органы Mintonia tauricornis: 87 - Внешний вид самки, дорзально; 88 - внешний вид самца, сбоку; 90-92 - пальпа, снизу и сбоку, и два аспекта эмболюса; 93-95 - эпигина, снизу и сзади, и её внутреннее строение.

DISTRIBUTION. Documented from Indonesia: Sumatra: Gunung Leuser National Park and from Malaysia: Borneo I.: Sarawak.

\section{Genus Nannenus Simon, 1902}

Type species Nanneus syrphus Simon, 1902 from Singapore.

REMARK. Poorly known SE Asian genus of uncertain relationships [Maddison et al., 2008: 59], originally placed by Simon [1903a: 770, 792] in the huge group of genera Hasarieae, which can no longer be sustained.

DIAGNOSIS. Genus recognizable by shape and proportions of internal structures of the epigyne (Figs 104-107), and by the structure of the palpus in males (Figs 98-100).

DESCRIPTION. Body of rather general appearance as illustrated by drawings of male $N$. syrphus, the type species of the genus [Prószyński, 1987: 69-70], and the female of $N$. maughami sp.n. (Figs 96-97). The latter has a longer abdomen, this difference presumably due to differences between the sexes. Palpus with bulbus elongate oval, long, positioned slightly diagonally in relation to main axis of the cymbium (Figs 98, 100). Spermophor duct runs along margin of bulbus. Embolus arises from posterior part of bulbus and runs laterally to it, extending further along tip of cymbium. Tibial apophysis plate-like, apically bent.

The cheliceral dentition developed differently in various species, there is a difference between left and right chelicera in the male of $N$. lyriger Simon, 1902 in Simon's collection [Prószyński, 1984b: 90-91].

Epigyne in Nannenus has a pair of grooves, oval or round, separated by a ridge (Figs 101-103). Copulatory opening near mid-length of epigyne, followed by membranous broad loop of a copulatory duct, passing into narrower sclerotized duct, with armature of scent gland opening near the junction. Sclerotized duct runs forwards initially, then makes a prominent bend and runs backwards along mid-line of epigyne, ultimately 

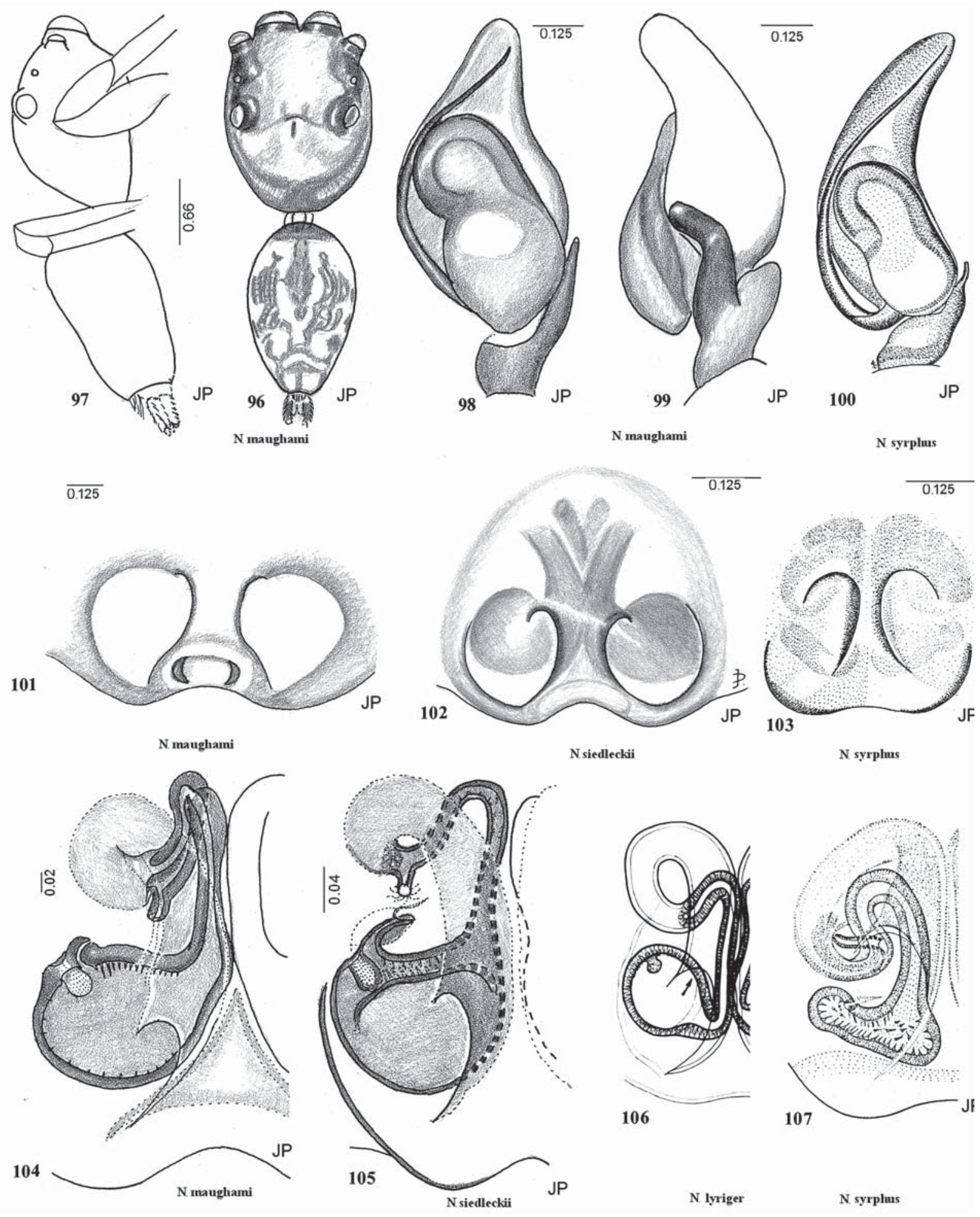

Figs 96-107. General appearance and copulatory organs of Nannenus maughami sp.n. (97-99, 101, 104), N. siedleckii sp.n. (102, $105), N$. lyriger (106) and N. syrphus $(100,103,107)$ : 96-97 - general appearance of female, dorsal and lateral views; $98-100-$ palpus, ventral and lateral views; 101-107 — epigyne and its internal structures.

Рис. 96-107. Внешний вид и копулятивные органы Nannenus maughami sp.n. (97-99, 101, 104), N. siedleckii sp.n. (102, 105), N. lyriger (106) и $N$. syrphus $(100,103,107)$ : 96-97 - внешний вид самки, дорзально и сбоку; 98-100 — пальпа, снизу и сбоку; 101107 - эпигина и её внутреннее строение. 

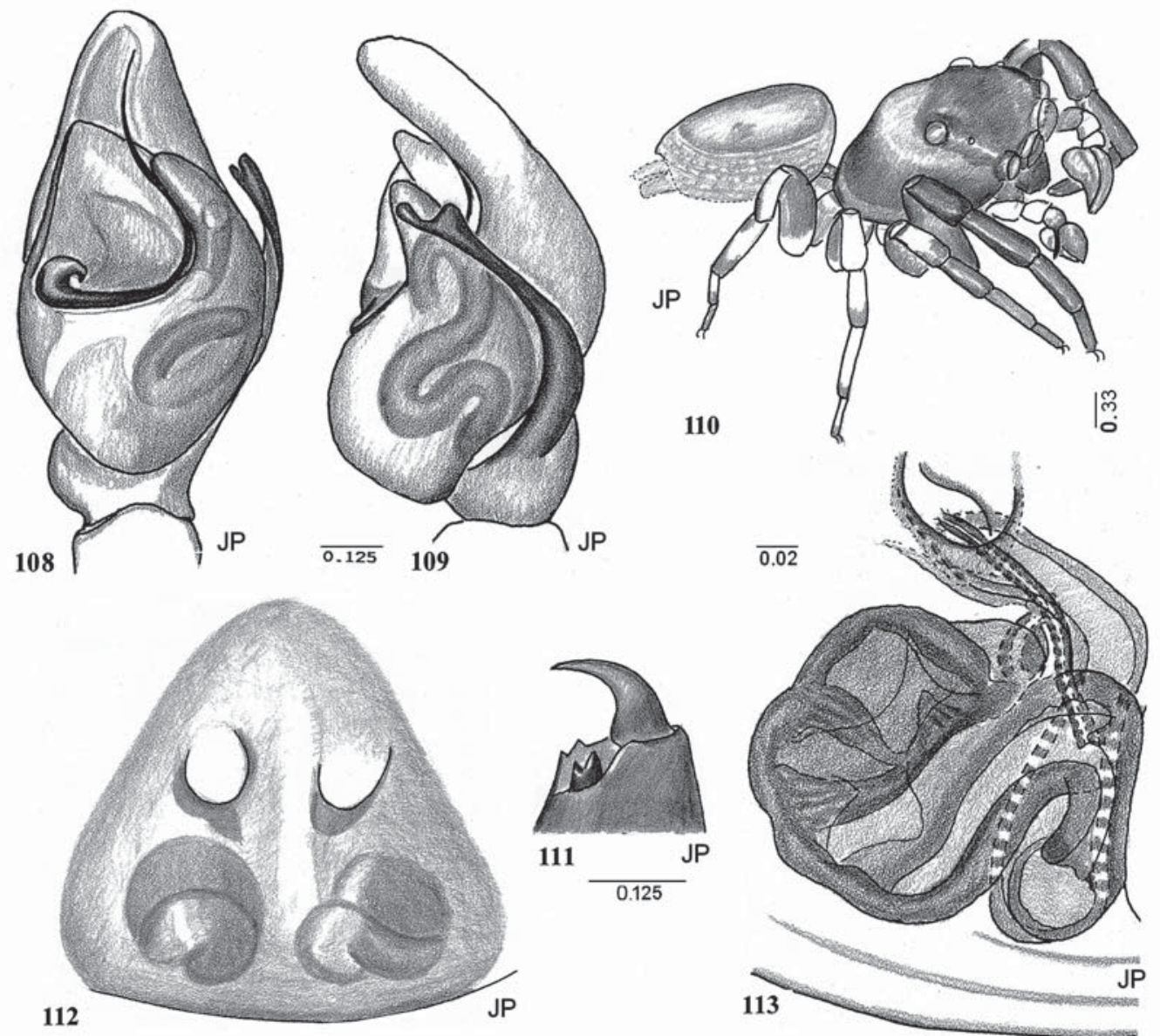

Figs 108-113. General appearance and copulatory organs of Orcevia kuloni sp.n.: 108-109 — palpus, ventral and lateral views; 110 - general appearance; 111 - cheliceral dentition; 112-113 - epigyne and its internal structures.

Рис. 108-113. Внешний вид и копулятивные органы Orcevia kuloni sp.n.: 108-109 - пальпа, снизу и сбоку; 110 — внешний вид; 111 — вооружение хелицер; 112-113 — эпигина и её внутреннее строение.

joining single-chambered spermatheca, which in N. lyriger, N. maughami sp.n. and N. siedleckii sp.n. is globular, but in N. syrphus is transversely flattened (Figs 104-107).

DISTRIBUTION. Two species known from Singapore, two newly described from Indonesia: Sumatra. Generic placement of $N$. constrictus (Karsch, 1880), from Philippines require confirmation.

\section{Nannenus maughami sp.n.}

Figs 97-99, 101, 104.

MATERIAL. Holotype $q$ and allotype $\sigma^{7}$, Sumatra: Bohorok, sink C, leaf litter 25 April, 1982. Leg. S. Djojosudharmo. CDML.

COMPARATIVE MATERIAL. + SYNTYPE Nannenus lyriger Simon, 1902, Singapore 14293 - coll. Simon. MNHN. (See Fig. 106). O'어 SYNTYPES Nanneus syrphus Simon, 1902. Singapore 11835. Coll. Simon MNHN. (See Figs 100, 103, 107).

ETYMOLOGY. Named after William Somerset Maugham (1874-1965) British novelist and short story writer.
DIAGNOSIS. The male differs from $N$. syrphus by its shorter embolus, the tip of the cymbium, and by its broader tibial apophysis (Fig. 99). The female (Fig. 104) differs by having a very tight anterior loop of the sclerotized copulatory duct, the membranous loop is distinctly smaller than in N. syrphus (Figs 107), and the spermatheca is globular rather than flattened.

DESCRIPTION. Male. Somatic characters are not documented. Tibial apophysis flat, apically bent (Figs 98-99). Palpus with elongate cymbium, gently bent. Bulbus elongate oval, set obliquely, with spermophor along edge, embolus arising from posterior angle of bulbus, running parallel to bulbus and extending distinctly in front of it.

Female. Body shown in Figs 96-97, with carapace as long as abdomen, but slightly broader, high, total length of body 3.0. Grooves of epigyne (Fig. 101) almost round, but narrowing posteriorly and ending angularly, posterior pocket single, triangular and poor- 

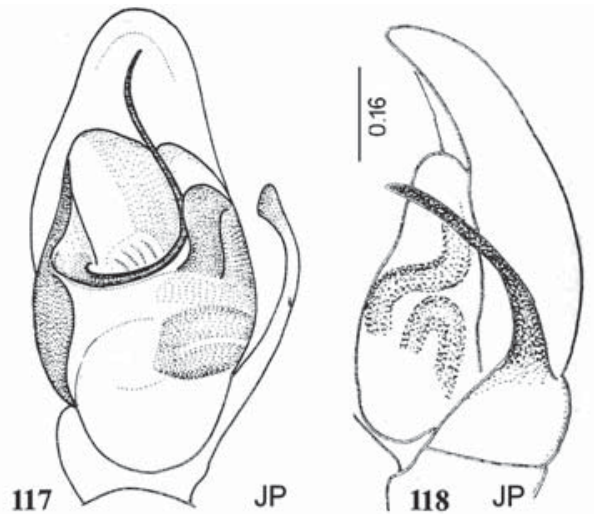

Orcevia keyserlingi
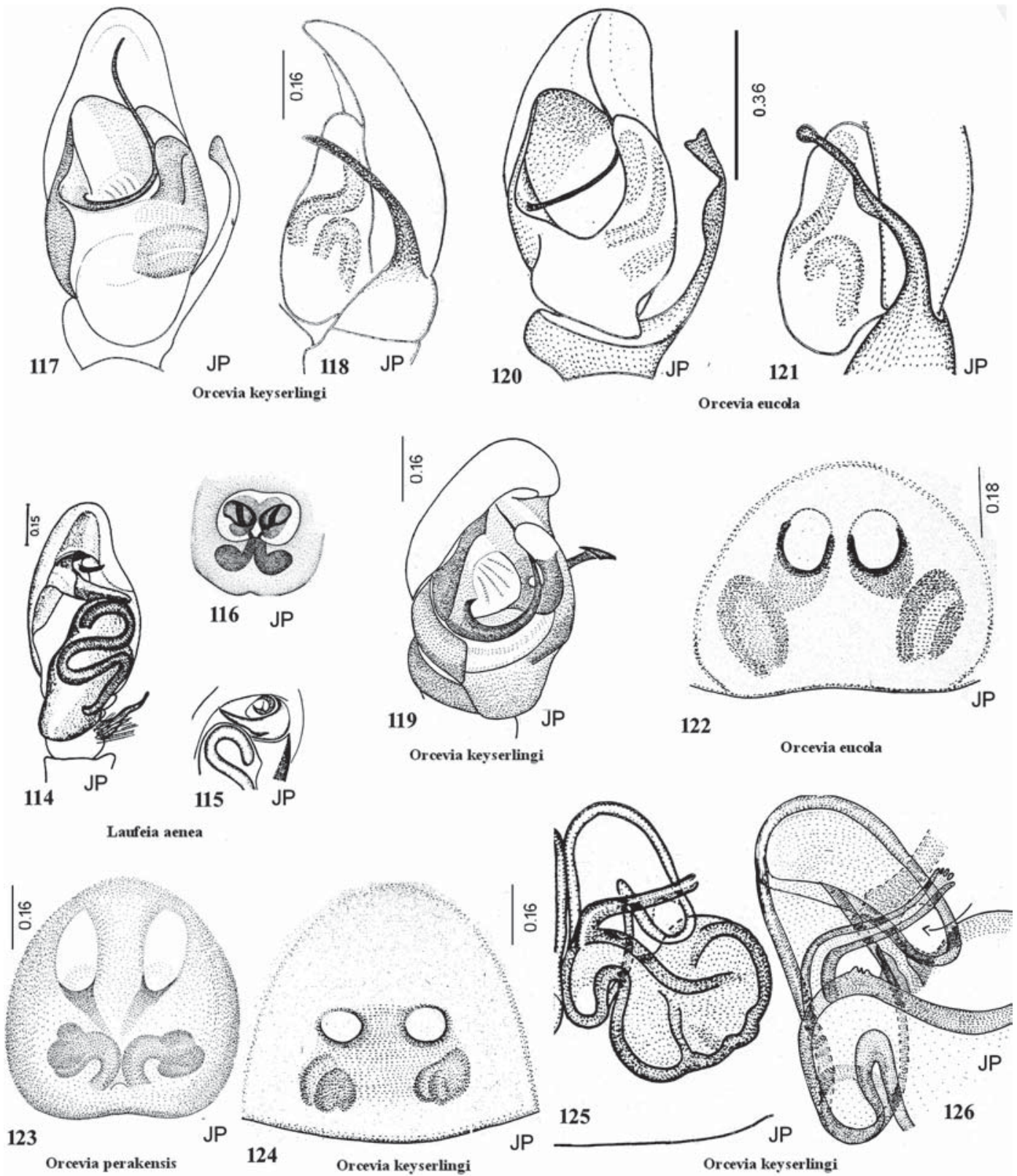

Orcevia keyserlingi

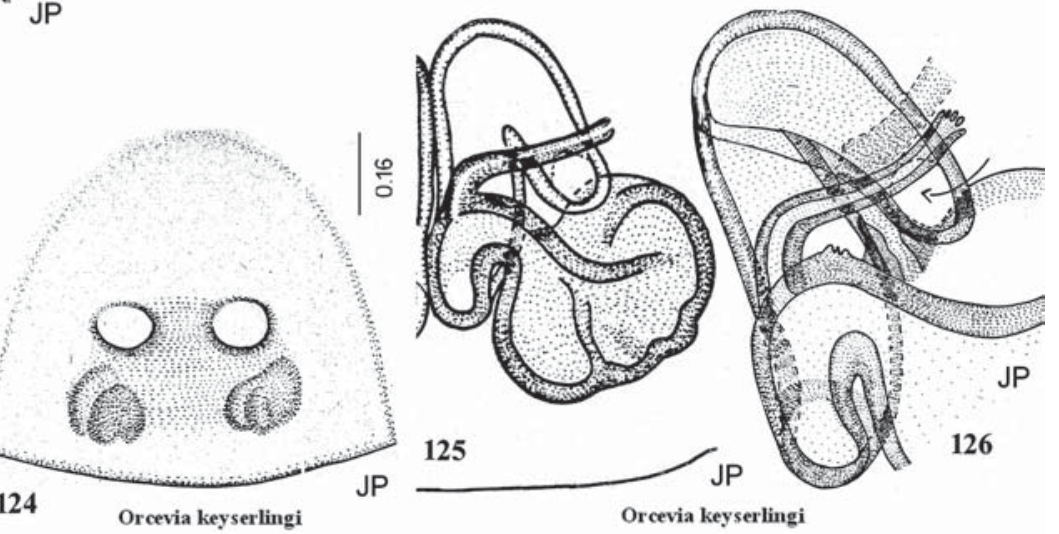

Figs 114-126. Copulatory organs of Laufeia aenea (114-116), Orcevia keyserlingi (117-119, 124-126), O. eucola (120-122) and O. perakensis (123): 114-115, 117-121 — palpus, ventral and lateral views; 116, 122-124 — epigyne; 125-126 — internal structures of epigyne and magnified detail of its copulatory duct and scent opening armature. 114-116 — after Bohdanowicz \& Prószyński [1987]; 120-122, 124-126 — after Prószyński [1984b]; 123 — after Prószyński [1987].

Рис. 114-126. Копулятивные органы Laufeia aenea (114-116), Orcevia keyserlingi (117-119, 124-126), O. eucola (120-122) и O. perakensis (123): 114-115, 117-121 - пальпа, снизу и сбоку; 116, 122-124 - эпигина; 125-126 - внутреннее строение эпигины. 114-116 — по Bohdanowicz \& Prószyński [1987]; 120-122, 124-126 — по Prószyński [1984b]; 123 — по Prószyński [1987].

ly visible. Sclerotized part of copulatory duct very narrow (Fig. 104), ascending part of the loop adjacent to the descending one, armature of the scent opening prominent, chimney-like, seems to be extended by thin membranous duct. Spermatheca almost globular.

DISTRIBUTION. Documented from Indonesia: Sumatra.

\section{Nannenus siedleckii sp.n.}

Figs 102, 105.

MATERIAL. Holotype + , Sumatra: Mt. Singalang, Anai. [Collector and date unknown]. CDML.

ETYMOLOGY. Named after Michał Marian Siedlecki, prominent Polish zoologist who collected zoo- 


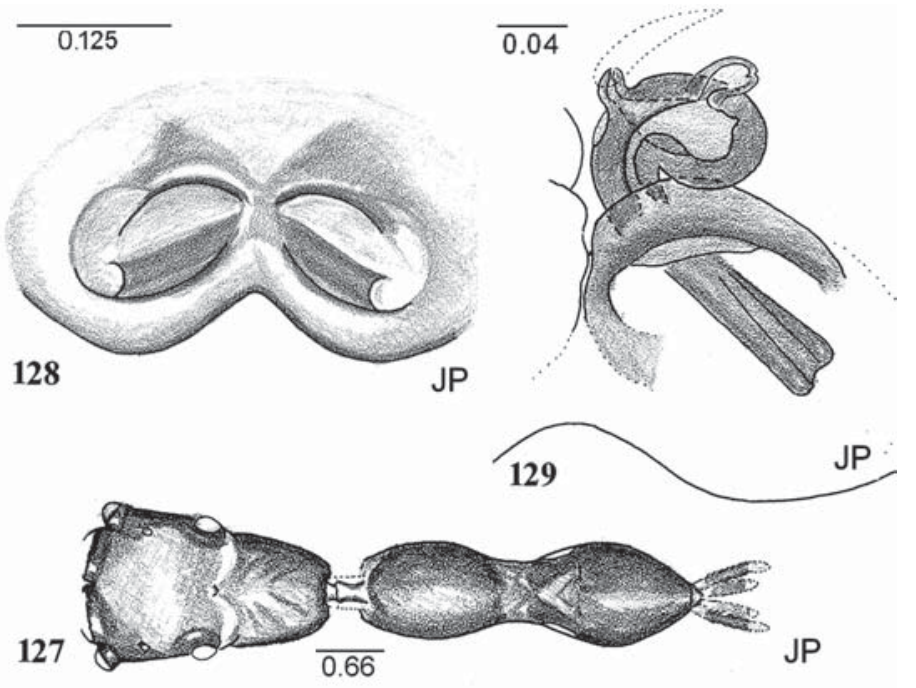

Figs 127-129. General appearance and copulatory organs of Orsima thaleri sp.n.: 127 - general appearance, dorsal view; 128-129 - epigyne and its internal structures.

Рис. 127-129. Внешний вид и копулятивные органы Orsima thaleri sp.n.: 127 - внешний вид, дорзально; 128-129 - эпигина и её внутреннее строение.
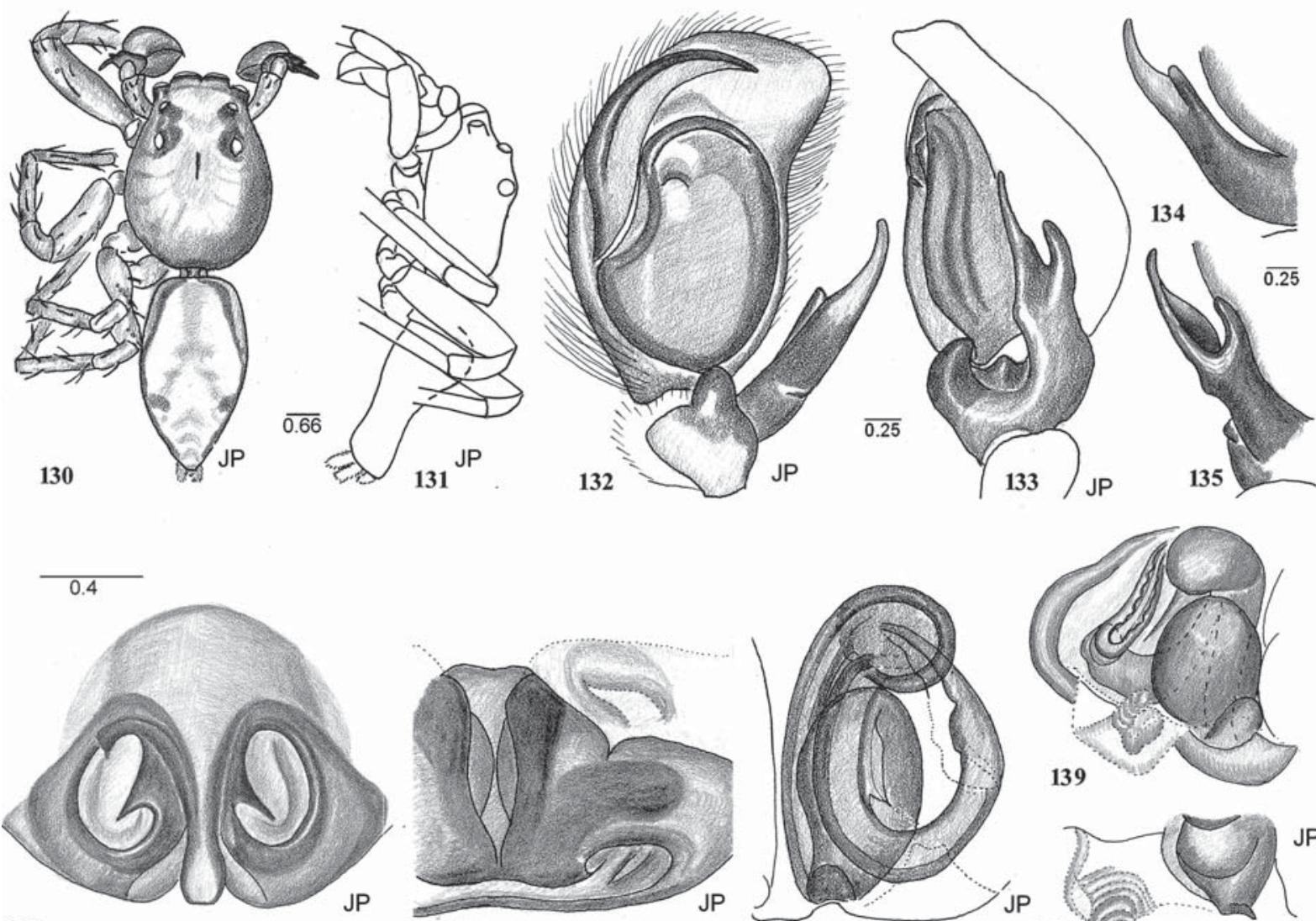

136
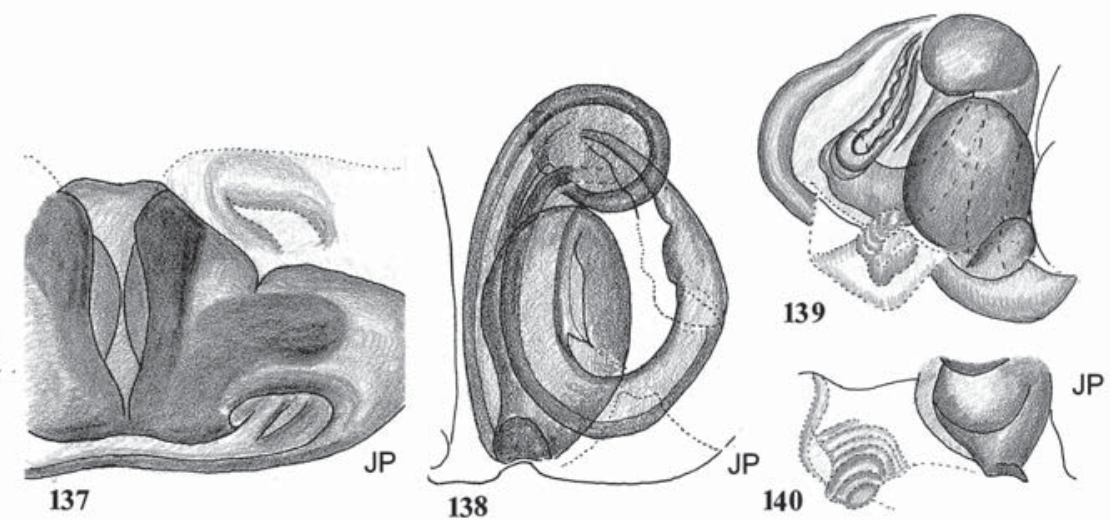

Figs 130-140. General appearance and copulatory organs of Phaeacius fimbriatus: 130-131 - general appearance, dorsal and lateral views; $132-135$ - palpus, ventral and lateral views and details of tibial apophysis; $136-137$ - epigyne, ventral and posterior view; 138140 - internal stuctures of epigyne, dorsal and antero-dorsal views, as well as strange membranous structure.

Рис. 130-140. Внешний вид и копулятивные органы Phaeacius fimbriatus: 130-131 - внешний вид, дорзально и сбоку; 132135 - пальпа, снизу и сбоку и детали строения отростка голени; 136-137 - эпигина, снизу и сзади; 138-140 - внутренняя структура эпигины, дорзально и спереди-сверху, а также необычная мембранизированная структура. 

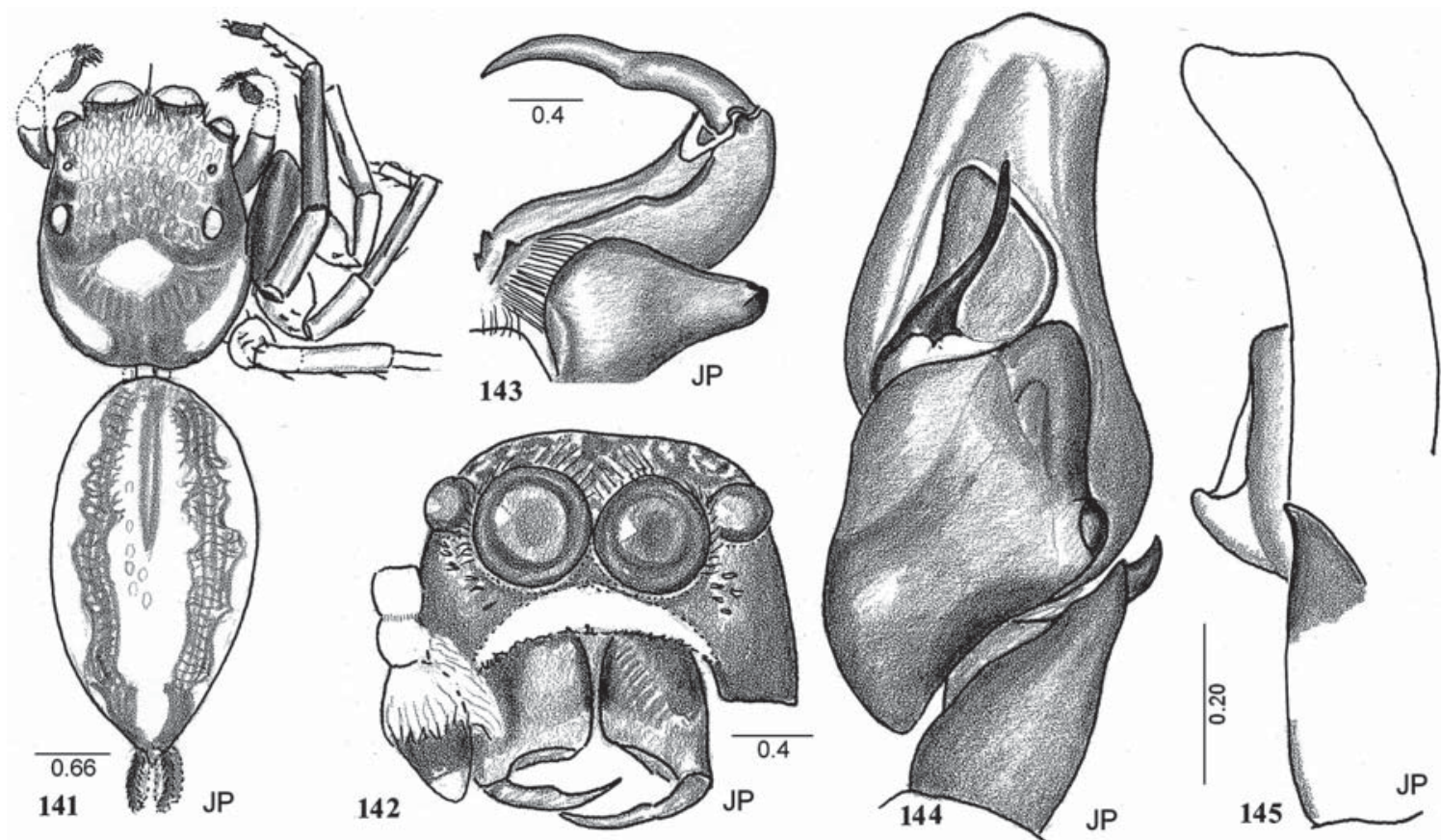

Figs 141-145. General appearance and copulatory organs of Phintella conradi sp.n.: 141-142 - general appearance, dorsal and frontal views; 143 - chelicera and maxillary endite; 144-145 - palpus, ventral and lateral views.

Рис. 141-145. Внешний вид и копулятивные органы Phintella conradi sp.n.: 141-142 - внешний вид, дорзально и спереди; 143 - хелицера и максиллы; 144-145 - пальпа, снизу и сбоку.

logical specimens, including spiders, from Java in 1907. In October 1939 he was sent to the Concentration Camp Sachsenhausen by Nazi-Germans, together with 168 other professors of the Jagiellonian University, where he died in 1940.

DIAGNOSIS. Recognizable by the epigyne which resembles $N$. maughami sp.n., but differs from it by having the grooves almost round (Fig. 102) and by a loose bend of the sclerotized duct (Fig. 105), as well as a horizontal ledge across the spermatheca. It differs from $N$. lyriger (Fig. 106) by having the copulatory duct joining the anterior part of spermatheca.

DESCRIPTION. Male unknown. Female. Somatic characters are not documented. Epigyne with grooves almost round (Fig. 102). Internal structures of epigyne (Fig. 105) with broad bend of sclerotized part of copulatory duct. Globular spermatheca is divided by sclerotized ledge, separating narrow anterior space which extends the duct (Fig. 100). Terminal opening of spermatheca atop of narrow extended cone, which seems to be a unique character.

REMARKS. Species recognized and described from the internal structure of the epigyne. Description of somatic characters of the female, and description of the male must be delayed pending further research.

DISTRIBUTION. Documented from Indonesia: Sumatra.
Genus Orcevia Thorell, 1890

Type species Orcevia keyserlingi Thorell, 1890, from Sumatra.

REMARKS. Simon [1903a: 824] synonymized the generic name Orcevia with Laufeia Simon, 1889 (type species L. aenea Simon, 1889). However, the genital organs of both sexes in Orcevia (Figs 117-126) are so different from L. aenea (Figs 114-116) that they cannot be congeneric (see diagnosis below), so we propose to consider the above as separate genera. Our knowledge of Laufeia is incomplete because the arachnological literature lacks illustrations of the general appearance of the male and of the internal structure of the epigyne.

We propose to include the following species into genus Orcevia:

Laufeia eucola $($ Thorell, 1890) = Orcevia eucola Thorell, 1890 from Sumatra.

Laufeia keyserlingi (Thorell, 1890) = Orcevia keyserlingi Thorell, 1890 from Sumatra (type species of the genus).

Laufeia perakensis (Simon, 1901) = Orcevia perakensis Simon, 1901 from Malaysia: Malay Peninsula

Laufeia proszynskii Song, Gu et Chen, $1988=$ Orcevia proszynskii (Song et al., 1988) comb.n. from China: Hainan. 


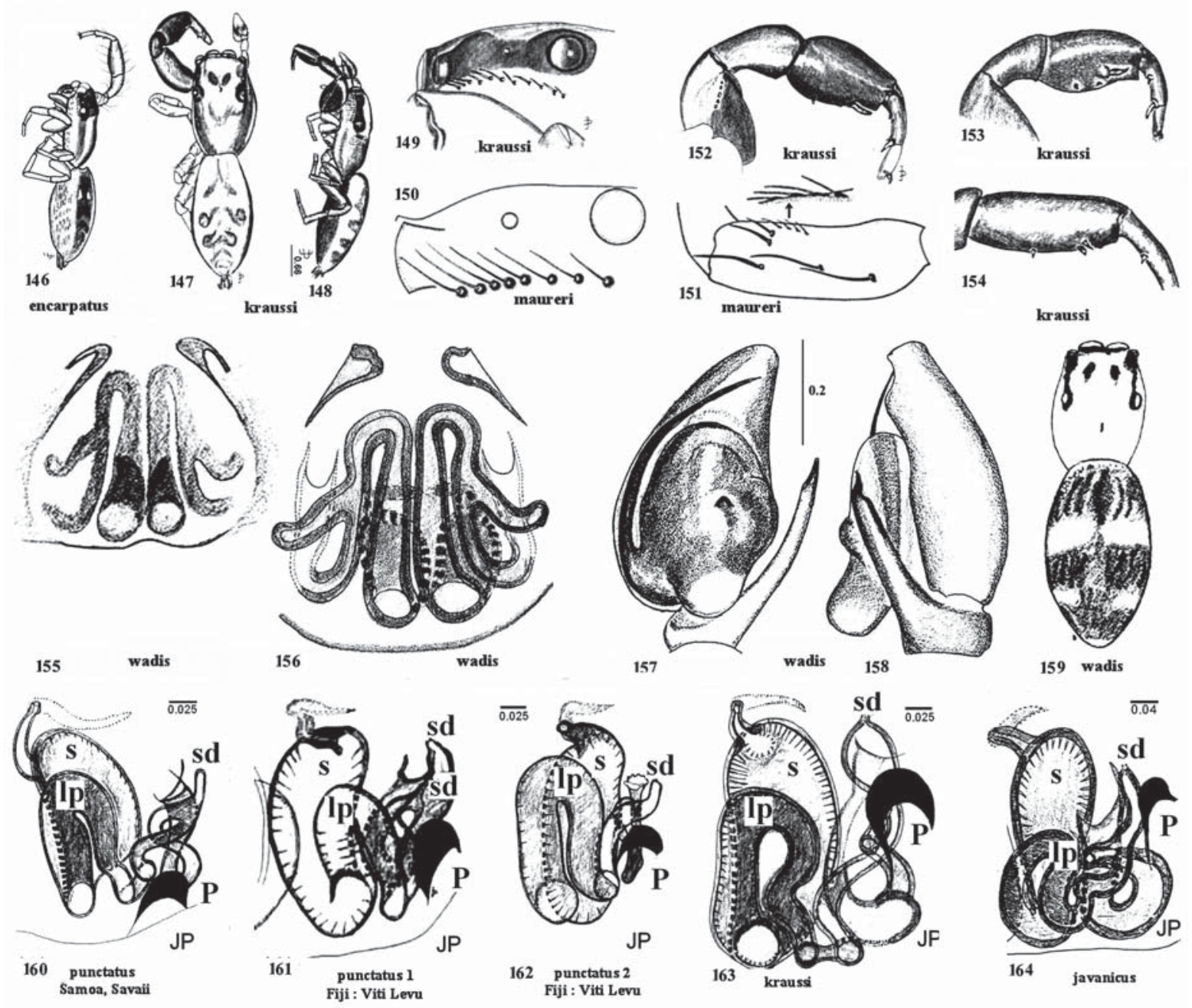

Figs 146-164. Some features of the genus Pseudicius. P. encarpatus (146), P. javanicus sp.n. (164) ), P. kraussi (147-149, 152-154, 163), P. maureri (150-151), P. punctatus (160-162), P. wadis (155-159): 164-148, 159 - general appearance; 149-150 - subocular row of stridulatory tubercles with spines; 151 - stridulatory microspines on femur I; 152-154 - diversity in modification of tibia I; 160 164 - diversity in copulatory ducts, spermathecae and pockets (abbreviations: $\mathrm{cc}$ — copulatory opening and duct, la — anterior loop of the copulatory duct, $1 \mathrm{p}$ - posterior loop of the copulatory duct, $\mathrm{P}$ - lateral pocket (black), s — spermatheca, sd — scent opening and duct, $\mathrm{T}-\mathrm{T}$ junction of scent duct and anterior, as well as posterior copulatory duct). 147-149, 152-154 — after Berry et al. [1998], 150151 - after Prószyński [1992]; 155-159 — after Prószyński [2003].

Рис. 146-164. Некоторые признаки рода Pseudicius. P. encarpatus (146), P. javanicus sp.n. (164) ), P. kraussi (147-149, 152-154, 163), P. maureri (150-151), P. punctatus (160-162) и P. wadis (155-159): 164-148, 159 — внешний вид; 149-150 - ряд стридуляционных бугорков с шипиками; 151 - стридуляционные шипики на бедре I; 152-154 - разнообразие модификации голени I; 160-164 - разнообразие семяпроводов, сперматек и карманов. 147-149, 152-154 — по Berry et al. [1998], 150-151 — по Prószyński [1992]; 155-159 — по Prószyński [2003].

The genus Laufeia contains currently the following species:

L. aenea Simon, 1889 - from Japan and China (type species of the genus),

L. sasakii Ikeda, 1998 - from Japan and

L. scutigera Zabka, 1985 - from Vietnam (placement to be revised).

DIAGNOSIS. Palpus of Orcevia males (Figs 117121) differs from that in Laufeia (Figs 114-115) by having a strikingly broader bulbus, long, loose coil of the embolus, long tibial apophysis terminating in a broad plate. Epigyne of Orcevia (Figs 122-124) dif- fers from Laufeia (Fig. 116) by having complicated internal structures; externally the epigyne has a pair of small white "windows" in front of semicircular rims of the copulatory openings.

DESCRIPTION. General appearance well illustrated by that of the male $O$. kuloni sp.n. (Fig. 110), see also description below. Palpus have long and gently bent tibial apophysis, terminating in a broad plate (Figs 108-109), bulbus broad, embolus long, forming a broad, loose coil.

Female. Somatic characters are not documented. Epigyne of Orcevia has a pair of small white "win- 


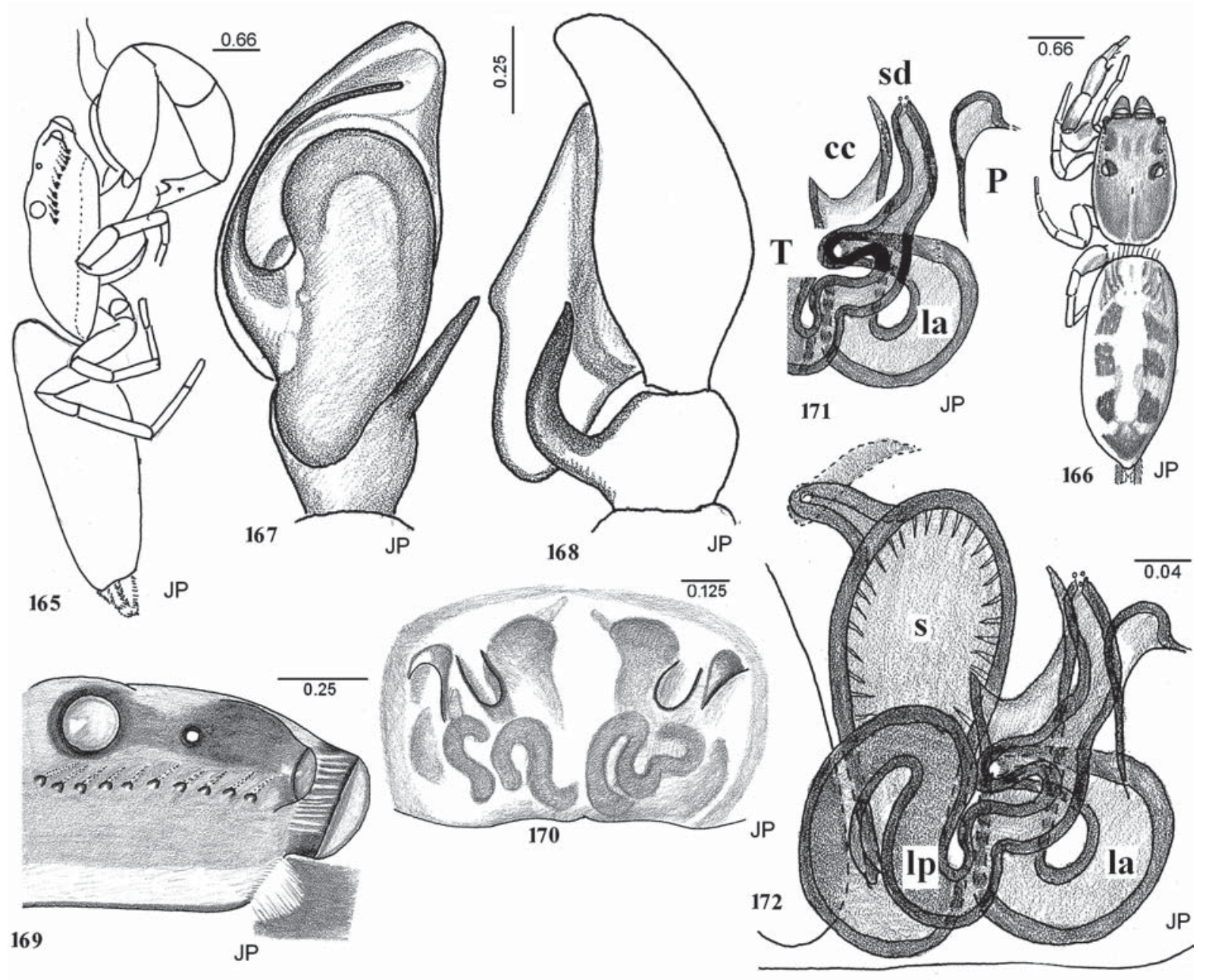

Figs 165-172. General appearance and copulatory organs of Pseudicius javanicus sp.n.: 165-166 - general appearance, lateral and dorsal views; 169 - a row of stridulatory spines on tubercles under eyes lateral; $167-168$ — palpus, ventral and lateral views; $170-172$ epigyne, its internal structures and diagram of separated parts of internal structures (abbreviations: cc — copulatory opening and duct, la - anterior loop of the copulatory duct, $\mathrm{lp}$ - posterior loop of the copulatory duct, $\mathrm{P}$ - lateral pocket, s — spermatheca, sd — scent opening and duct, T - T junction of scent duct and anterior, as well as posterior copulatory duct).

Рис. 165-172. Внешний вид и копулятивные органы Pseudicius javanicus sp.n.: 165-166 - внешний вид, сбоку и дорзально s; 169 — ряд стридуляционных шипиков на бугорках под глазами, сбоку; 167-168 — пальпа, снизу и сбоку; 170-172 - эпигина, её внутреннее строение и диаграмма отдельных частей.

dows" in front of semicircular rims of the copulatory openings, in the mid-length (Figs 122-124). Internal structures unusual, with copulatory ducts long and bent, sclerotized spermatheca compact, with internal ducts and convoluted chambers, armature of scent gland opening resembling a long pipe (Figs 125-126).

\section{Orcevia kuloni sp.n.}

Figs 108-113.

MATERIAL. Holotype $\sigma^{\top}$, allotype $q$, W Java: Udjung Kulon reserve, leaf litter, 14-25 November, 1986. Leg. C.L. \& P.R. Deeleman. CDML.

ETYMOLOGY. Named for Udjung Kulon reserve, where collected.
DIAGNOSIS. The male differs from $O$. keyserlingi by having a broader bulbus and a tibial apophysis with a forked terminal plate (Figs 108-109). The female differs by the triangular outline of the epigyne (Fig. 112), more compact spermatheca, and shorter copulatory ducts in front of the spermathecae (Fig. 113).

DESCRIPTION. Male. Dark, without any distinct dorsal pattern, flat area of thoracic region lighter. Narapace high and short, 1.8 long, posterior slope steep, eyefield slightly broader than long, narrowing posteriorly (Fig. 110). Abdomen oval, 1.6 long, covered dorsally with scutum. Inner posterior cheliceral tooth has two cusps (Fig. 111). Legs I longest and most robust.

Palpus with long tibial apophysis, reaching tip of bulbus, relatively thin and gently bent, expanded dis- 


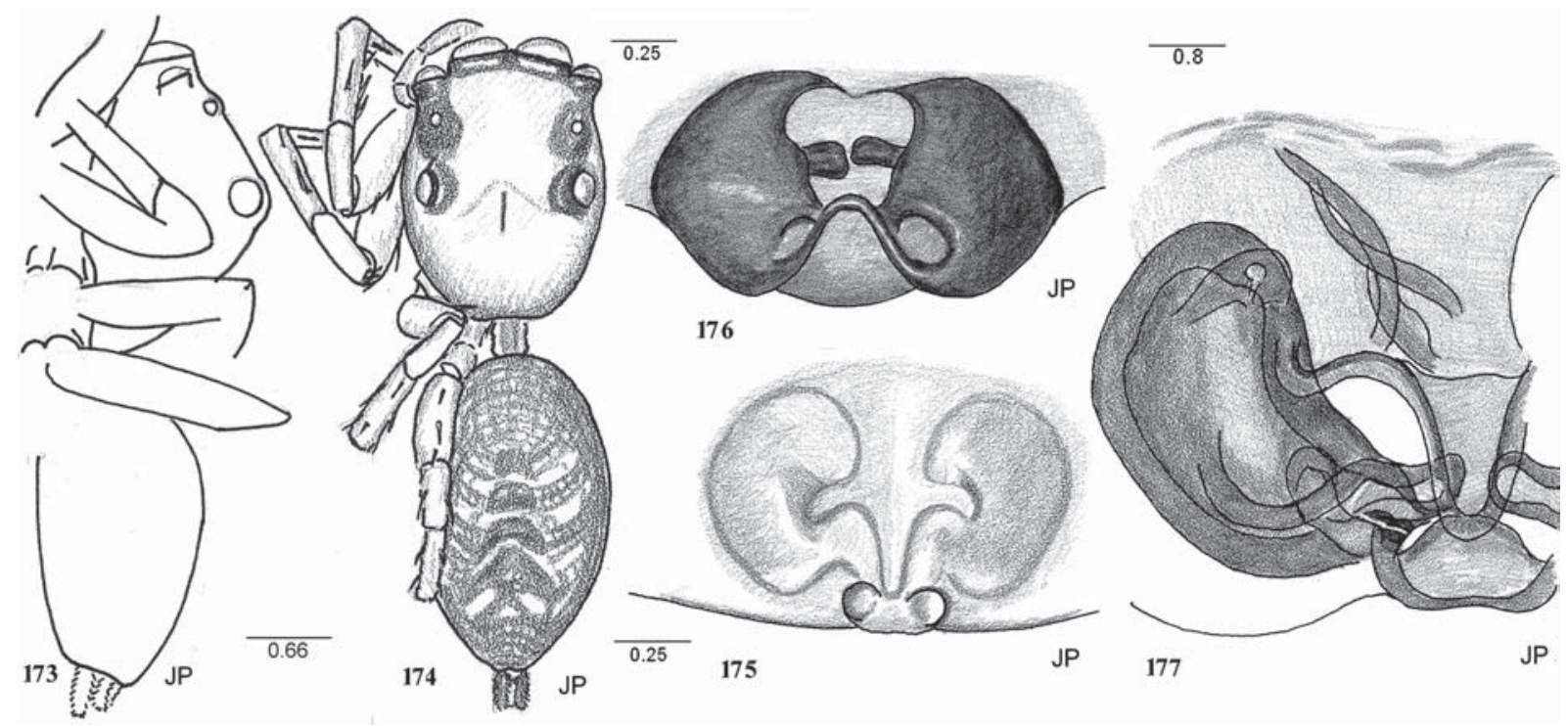

Figs 173-177. General appearance and copulatory organs of Taraxella sumatrana: 173-174 - general appearance, dorsal and lateral views; $175-177$ - epigyne, ventral and posterior views, as well as internal structures.

Рис. 173-177. Внешний вид и копулятивные органы Taraxella sumatrana: 173-174 — внешний вид, дорзально и сбоку; 175177 - эпигина, снизу и сзади, и внутреннее строение.

tally into a small plate, bifurcated apically with unequal, short but broad rami. The bulbus is broad, the embolus forming a broad loop atop the bulbus, oriented in a diagonal plane (Figs 108-109).

Female. Somatic characters are not documented. Epigyne oval with a pair of small "windows" in the anterior half (Fig. 112). Copulatory ducts sclerotized, spermathecae compact, divided internally into convoluted chambers and ducts (Figs 113). Armature of the scent opening in the form of a long duct, ending at the level of the copulatory opening.

DISTRIBUTION. Documented from Indonesia: Java.

\section{Genus Orsima Simon, 1901}

Type species Orsima constricta Simon, 1901 from West Africa.

REMARKS. This genus is tentatively placed in the subfamily Heliophaninae. Despite its ant-like shape it is not related to Myrmarachne MacLeay, 1839. Species are known from Africa $(O$. constricta) and South Asia (O. ichneumon (Simon, 1901)), and are characterized by a long, narrow abdomen, with a constriction in the posterior region, resulting in a swollen, rounded end. However, the congeneric status of these species seems doubtful in view of difference in their pedipalp structure. The synonymy of the Bornean O. formica Peckham et Peckham, 1907 and the Sumatran O. ichneumon, proposed by Żabka [1992] is not convincing. They have a colourful body — see photographs by D. Knowles, reproduced in Prószyński [2011].

\section{Orsima thaleri sp.n.}

Figs $127-129$.

MATERIAL. Holotype + , Sumatra: Mt. Singalang, Anai (480$520 \mathrm{~m}$ ), secondary forest, from leaves, 10-22 June, 1994. Leg. S. Djojosudharmo. CDML.

ETYMOLOGY. Named after Konrad Thaler (19402005) — a prominent Austrian arachnologist and a friend of the authors. His activities included efforts to promote conference etc. participation of arachnologists from the Socialist Countries', especially during the years 1986-1989, when he was President of the International Society of Arachnology (then named CIDA).

DIAGNOSIS. The new species differs from $O$. ichneumon [see Żabka, 1992: figs 15-16] by the epigynal window having a robust sclerotized arch on its anterior rim (Fig. 128), the posterior location of the copulatory opening, and the oblique course of the duct towards the anterior spermatheca (Fig. 129).

DESCRIPTION. Male unknown. Female. Body elongate, with carapace narrowing posteriorly, but without constriction. Eyefield flat, narrowing posteriorly. Pedicel long, visible from above. Abdomen constricted, with posterior end globular (Fig. 127), thoracic region without constriction. Epigyne transversally oval, with prominent sclerotized arch at the anterior edge of the white "windows" (Fig. 128). Copulatory openings located at the postero-lateral part of transversely oval epigynal groove, from which thick-walled sclerotized copulatory duct runs antero-diagonally, and passes under the superficial, sclerotized arch of the groove's rim. Beyond that rim ducts bend laterally, making $120^{\circ}$ 

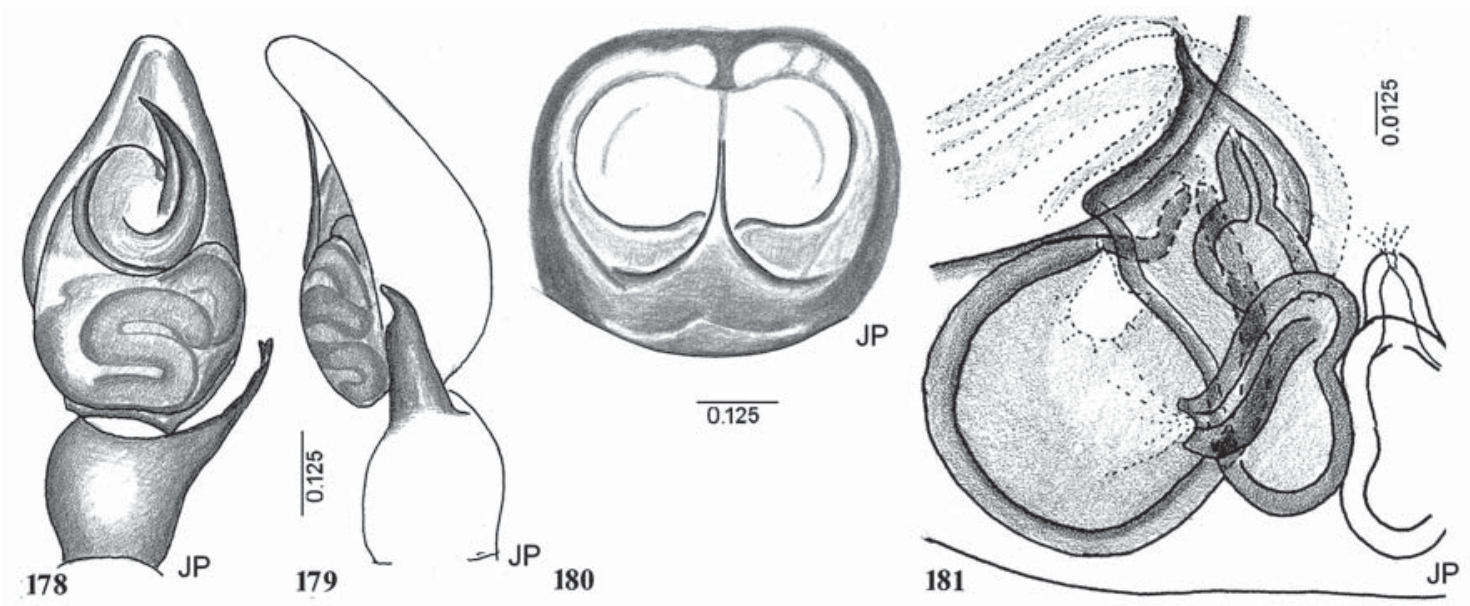

Figs 178-181. Copulatory organs of Thianitara spectrum: 178-179 — palpus, ventral and lateral views; $180-181$ - epigyne and its internal structures.

Рис. 178-181. Копулятивные органы Thianitara spectrum: 178-179 — пальпа, снизу и сбоку; 180-181 - эпигина и её внутреннее строение.

turn, to join globular, but transversely oriented spermatheca. Armature of the scent gland opening prominent, located on anterior wall of spermatheca (Fig. 129).

Measurements. Length of carapace 2.30, ratios: length of eyefield 0.57 , height of eyefield 0.41 , width of eyefield at eyes I 0.79 , width of eyefield at eyes III 0.75 , maximum width of carapace 0.79 , length of flat portion of carapace 0.67 , length of abdomen 1.48 , width of abdomen 0.52 , leg I (as ratio of length of carapace) 3.39. Length of legs ( 5 distal segments) in $\mathrm{mm}$ and as ratio to leg I: leg I $7.80=1.00$, leg II $5.06=0.65$, leg III $5.74=0.73$, leg IV 9.06 $=1.16$. Length of legs order: IV, I, III, II.

REMARKS. The internal structure of the epigyne of this species could be derived from $O$. ichneumon, by shifting the spermatheca forward and bending the sclerotized copulatory channel. Such internal modifications, while the external appearance is similar, may suggest local speciation and absence of intermediate species, which in turn may not support Żabka's [1992] hypotheses on the conspecificity of the Sumatran $O$. ichneumon and the Bornean O. formica Peckham et Peckham, 1907. Unfortunately the female is unknown in the latter species.

DISTRIBUTION. Documented from Indonesia: Sumatra.

Gen. Petemathis gen.n.

Figs 187-197. 1930.

Type species Emathis portoricensis Petrunkevitch,

ETYMOLOGY. The proposed new generic name combines part of the name of Alexander Petrunkevitch (with intention of paying respect to the memory of that prominent Arachnologist) and of originally used name Emathis, grammatical gender - feminine.
DIAGNOSIS. Males of three species described by Petrunkevich have Euophryinae type of palpi, with small coil of embolus atop bulbus (Figs 190-193), while SE Asian Emathis have large coil extending over half of ventral surface of bulbus (Figs 27-30). Females of all four species have a pair of large "windows" on the ventral surface of epigyne (Figs 194-197), entirely different from the SE Asian Emathis (Figs 31-33). Both sexes of all species of Emathis and Petemathis have saw-like cheliceral tooth (Fig. 187).

DESCRIPTION. We refer reader to the descriptions given by Petrunkevitch, 1930: 118-135, figs 97119. The diagnostic drawings are also shown in Prószyński, 2011. Descriptions by Franganillo, 1930 [: $38]$ and 1936 [: 130] seem insufficient for recognition of the species Petemathis unispina (Franganillo, 1930).

REMARKS. Four Porto Rican Euophryinae species with saw-like cheliceral tooth were originally described by Petrunkevitch 1930 in the unrelated Oriental genus Emathis Simon. One more species, from Cuba, was added to them by Franganillo, 1930. There are no similar genital organs among drawings of 82 species of Euophryinae from South America, or from 100 species from Central America and the Caribbean, so these species should be transferred to a new genus.

Misplacement of these was realized by Bryant [1940: 466], and was subsequently mentioned by Żabka, 1985 , as well as Barrion et Litsinger, 1995; Prószyński kept pointing that in all version of Salticidae database during years 1995-2011. However, students of Oriental Salticidae did not feel competent to describe Caribbean genus, and Arachnologists of the Western Hemisphere were apparently not interested in setting order in the fauna of their Region. To introduce some order in the taxonomy, the present authors decided to transfer Petrunkevitch's species into separate genus, in the hopes that this will stimulate further study by more competent Arachnologists. 

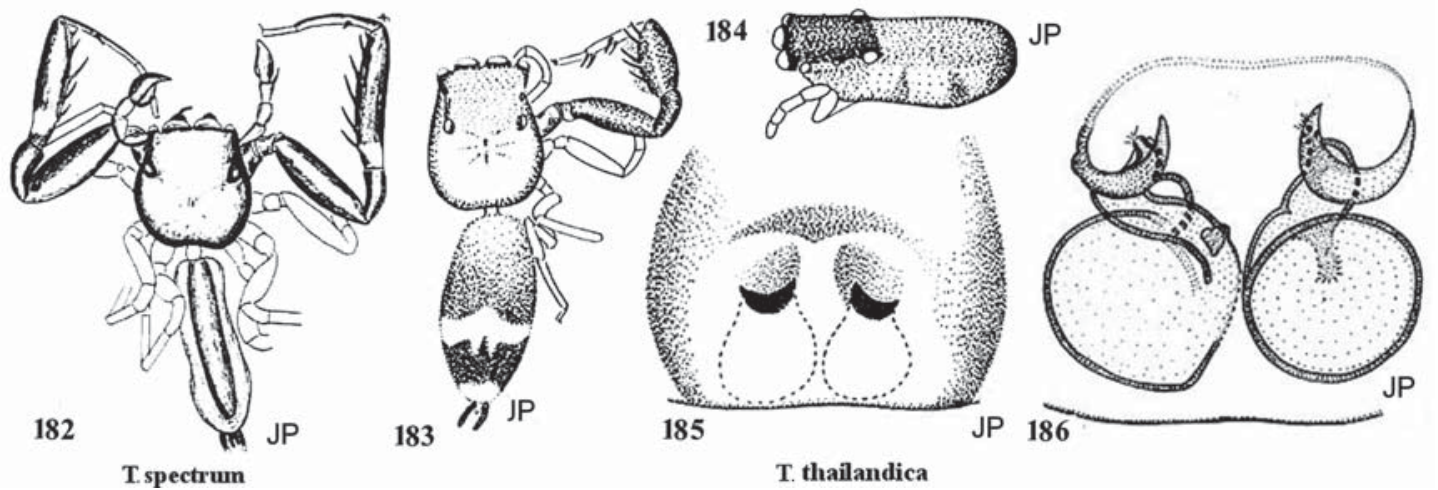

Figs 182-186. General appearance and copulatory organs of Thianitara spectrum (182) and Th. thailandica sp.n. (183-186): 182183 - general appearance; 184 — carapace; 185-186 — epigyne and its internal structure.

Рис. 182-186. Внешний вид и копулятивные органы Thianitara spectrum (182) и Th. thailandica sp.n. (183-186): 182-183 внешний вид; 184 — carapace; 185-186 — эпигина и её внутреннее строение.

\section{DISTRIBUTION. Porto Rico and Cuba.} cies:

The genus Petemathis contains the following spe-

Petemathis luteopunctata (Petrunkevitch, 1930) comb.n.

Emathis l. Petrunkevitch, 1930: 135, f. 117-119 (†).

Type specimens from Puerto Rico, kept in PMYU.

Petemathis minuta (Petrunkevitch, 1930) comb.n. Emathis m. Petrunkevitch, 1930: 130, f. 110-116 (○', +).

Type specimens from Puerto Rico, kept in AMNH.

Petemathis portoricensis (Petrunkevitch, 1930) comb.n.

Emathis p. Petrunkevitch, 1930: 118, f. 97-103 (०', ๆ).

Type specimens from Puerto Rico, kept in PMYU.

Petemathis tetuani (Petrunkevitch, 1930) comb.n. Emathis t. Petrunkevitch, 1930: 125, f. 104-109 (O', ㅇ).

Type specimens from Puerto Rico, kept in PMYU.

Petemathis unispina (Franganillo, 1930) comb.n. Emathis u. Franganillo, 1930: 38 ( $($ ).

Emathis u.: Franganillo, 1936: $130\left(0^{\top}\right)$.

Described from Cuba, whereabouts of types unknown.

\section{Phaeacius fimbriatus Simon, 1900}

Figs 130-140.

P.f. Simon, 1900: $32(+)$.

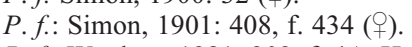

P. f.: Wanless, 1981: 202, f. 4A-H, 5B ( $\left(\right.$, $\left.\sigma^{7}\right)$.

P. f: Wanless, 1984: 190, f. 28A-H (O' $\%)$.

MATERIAL. 1 O' "Phaeacius lancearius: det. Kulczyñski. Java: Wonosobo, Mai 1909" [Misidentified]. MiIZ. 1 ㅇ "Phaeacius fimbriatus: Java; Tjibulan near Bogor. Leg. Pisarski, det. Prószyński”. MiIZ.

DIAGNOSIS. Differs from P. lancearius (Thorell, 1895) and P. malayensis Wanless, 1981 by longer dorsal ramus of the tibial apophysis and minor details of the palpus [see Wanless, 1981: 205, figs 1, 2, 5-7].

DESCRIPTION. Male. General appearance shown in Figs 130-131. Two tibial apophyses, the ventral one small, forming a short, broad hook, the retrolateral one long and robust, slightly bent, bifurcated in apical half, with rami of unequal length (Figs 132-135).

Measurements: length of carapace 3.63, of eye field 1.5, of abdomen 3.6; height of carapace at eyes III 1.8; width of eyefield at eyes I 1.6, maximum width of carapace 2.97, maximum width of abdomen 1.9.

Female. Carapace broad, with raised eyefield. Abdomen pointed, with posterior whitish diamond spot. Legs I-IV long and robust. Epigyne relatively large, with two oval depressions extending along the whole length, encircled by broad, black sclerotized rims, broadly separated (Figs 136-137). Internal structure is shown on Figs $138-139$, there is a membranous pocket of unknown function (Fig. 140), not observed in other species.

REMARKS. The type species of the genus was described from a female specimen, but accompanied by a male, not mentioned in the original description and only assumed to be conspecific by Wanless [1981: 202-205, f. 4A-H]. The existing drawings of the external views of the epigyne of $P$. malayensis, and the lack of similar for $P$. lancearius do not permit confirmation of Wanless's conclusions regarding differences.

DISTRIBUTION. Documented from Indonesia: Java, record from Nepal require confirmation.

\section{Phintella conradi $\mathbf{s p . n .}$}

Figs 141-145.

MATERIAL. Holotype $\sigma^{7}$, Sumatra: Mt. Singalang, Anai, 400$430 \mathrm{~m}$, secondary forest near the cave. Leg. S. Djojosudharmo. CDML.

ETYMOLOGY. Named after Joseph Conrad (Józef Teodor Konrad Korzeniowski, 1857-1924) — a Polish novelist who wrote in English, and for many years was a Merchant Navy captain sailing around the Malay Archipelago, as described in his novels. 


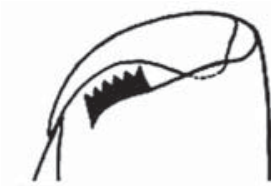

187 luteopunctata.

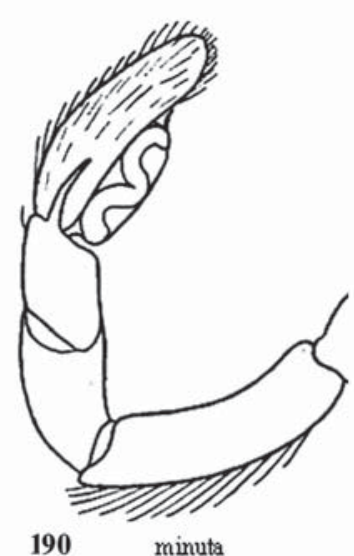

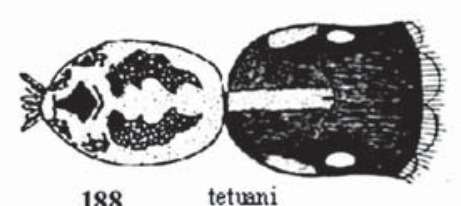

188

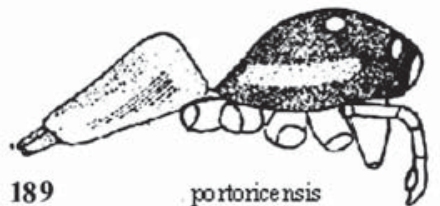

189

portoricensis

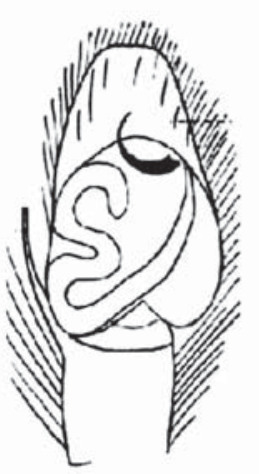

191
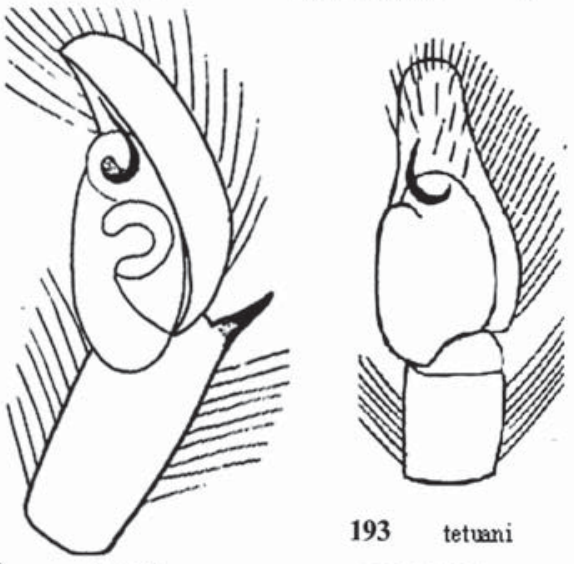

193 tetuani

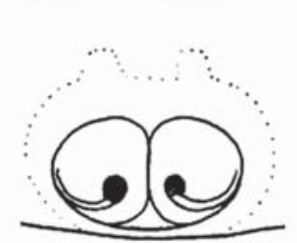

194
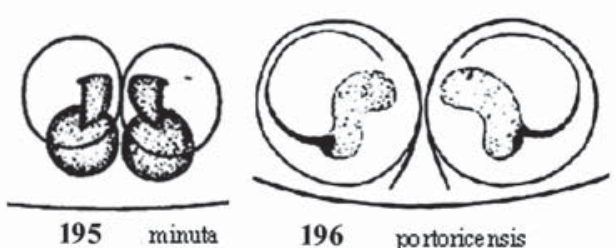

196

portoricensis

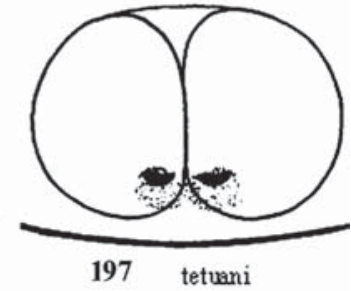

Figs 187-197. Diagnostic characters of the Caribbean genus Petemathis gen.n. Petemathis luteopunctata (187, 194), P. minuta (190191, 195), P. portoricensis $(189,196)$, P. tetuani $(188,192-193,197)$ : 187 - saw-like cheliceral tooth; 188-189 - general appearance, dorsal and lateral views; 190-193 — palpus, ventral and lateral views; 194-197 — epigyne. 187-197 — from Petrunkevitch 1930.

Рис. 187-197. Диагностические признаки карибского рода Petemathis gen.n.: Petemathis luteopunctata (187, 194), P. minuta (190-191, 195), P. portoricensis $(189,196)$, P. tetuani $(188,192-193,197)$ : 187 — пиловидный зубец хелицеры; 188-189 — внешний вид, дорзально и сбоку; 190-193 — пальпа, снизу и сбоку; 194-197 — эпигина. 187-197 — из Petrunkevitch [1930].

DIAGNOSIS. Resembles $P$. bifurcilinea (Bösenberg et Strand, 1906) (type species of the Phintella Bösenberg et Strand, 1906) by general appearance (Fig. 141). Palpal organ differs by having a bent plate, dorsal to the embolus (Fig. 144, absent in P. bifurcilinea). The lateral angle of the maxillary endite is drawn out into a long, triangular process (Fig. 143).

DESCRIPTION. Male. Body shape shown in Fig. 141. Length of carapace 2.3, length of abdomen 3 . Carapace with tegument dark, iridescent, with spots of white scales. Anterior half of eyefield lighter, with a white, diamond-shaped spot behind eyefield. Lower sides of thoracic region with white lateral streaks posteriorly. Eyefield rectangular. Anterior lateral eyes half the size of anterior medians, aligned with dorsal rim of the latter (Fig. 142). Abdomen elongate oval, pointed distally, as broad as carapace. Light coloured, with two grey streaks, also median grey streak, bisected by a dark thin line along anterior half (Fig. 141). Spinnerets dark. With exception for white clypeus, the following parts are black: face, chelicerae, lateral surfaces of leg I, median part of cymbium.
Anterior part of cymbium somewhat elongated, posterior part of bulbus drawn angularly, sperm duct bent anteriorly and running diagonally across the bulbus. Embolus running anteriorly, gently bent, about half the length of bulbus. There is a curious plate, dorsal to the embolus, as long as the embolus (Fig. 144), anteriorly angular and bent. Lateral angle of maxillary endite drawn out into long, triangular process (Fig. 143).

Female unknown.

REMARK. Placement in this genus is tentative, pending further comparative studies on the unusual plate located above the embolus.

DISTRIBUTION. Documented from Indonesia: Sumatra.

Genus Pseudicius Simon, 1885

Type species: Aranea encarpata Walckenaer, 1802, from Europe.

DEFINITION. A genus containing more than 90 species, recognizable first of all by their peculiar stridulatory apparatus and other somatic characters, including body short and long, legs I robust, longest in 
males (Figs 146-148, 159, 165-166). Genital organs variable, particularly complicated in females. Similar characters also occur in the small, closely related African genus Festucula Simon, 1901, although in this genus the abdomen is exceptionally long. The peculiarities of Pseudicius are most clear when compared with another well known Heliophaninae genus Menemerus Simon, 1868, which is speciose, widespread, and lives in the same type of environment.

DIAGNOSIS. Both sexes differ from Menemerus by the presence of a lateral subocular row of tubercles (Figs 149-150, 169) and microtubercles on femur I (Figs 151-152), and also by having a modified tibia I (Figs 152-154).

DESCRIPTION. Carapace with peculiar row of about 10 stridulatory bristles on tubercles, short and robust, stretching below the lateral eyes (Figs 149150, 169); these presumably interact [Maddison, 1987] with microscopic spines on anterior lateral surface of femur I (Figs 151-152). Abdomen oval and low, usually about twice as long as the carapace. Leg I robust and long in both sexes (Figs 165), although in females leg IV longer than leg I (Fig. 166). Tibia I modified, (Figs 151-153), either medianly swollen, or cylindrical, sometimes enlarged. Spines on tibia I reduced entirely, or short and thick, usually grouped ventro-distally. There are a few curious dorsal trichobothria on tibia I - long hairs, stiff and thin, often waving or apically bent.

Abdominal pattern variable, usually with prominent median dark streak (Fig. 146), or pairs of dark spots (Figs 147) on light background. These spots are often square or rectangular, stretching along the whole abdomen, or concentrated in its posterior region, the posterior single spot is diamond-shaped - fitting within angular end of abdomen. Genital organ structure diverse, both in males and females; the species can be arranged into forms showing gradual changes, hypothetically reflecting evolutionary relationships. Males have an oval bulbus with embolus arising laterally, tibial apophysis long and pointed (Figs 157-158, 167168), sometimes forked, with rami of various length. Females have long, coiled copulatory ducts, prominent, long structures of scent gland openings and oval spermathecae (Figs 156, 160-164).

REMARKS. Maddison et al. [2008] classify Pseudicius in the subfamily Heliophaninae, close to the North American genus Marchena Peckham et Peckham, 1909, based on molecular analysis. Both genera have stridulatory organs including tubercles with microspines on the femur, in Marchena, however, the subocular row of tubercles is replaced by a cuticular rugosity. The genus Pseudicius has diverse genital organs, hypothetically evolved from some common ancestral form. That diversity should be reflected in the subdivision of the genus - the first tentative split into informal species groups was presented in the database by Prószyński [2011]. The available data are, however, too incomplete for formal description of subgenera. The newly acquired data suggest that the frigidus group of species should be excluded from this genus.
DISTRIBUTION. The genus occurs in the continents of the Old World, Pacific Islands and Australia, is absent on the Western Hemisphere.

\section{Pseudicius javanicus sp.n.}

Figs 165-172.

MATERIAL. Holotype + , $\odot^{r}$ allotype, Jawa: Kagok + Probolingo. Kulczyński Coll. MiIZ.

ETYMOLOGY. Specific name derived from Java Island.

DIAGNOSIS. This species differs from males of $P$. wadis Prószyński, 1989 (Figs 157-158) by having a strongly bent tibial apophysis, resembling the letter "U" in lateral view (Fig. 168), females have a smaller loop in the copulatory duct, equal to half the length of the spermatheca (Figs 170-171).

DESCRIPTION. Male. Body appearance shown in (Fig. 165), but colors have changed after 100 years of storage in alcohol. Subocular row of stridulatory spines is distinct (Fig. 169). Legs I with oversized, much broadened femur, patella and tibia. Male palpus with elongate oval bulbus, embolus arising from a broad base, in midlength of bulbus, parallel to bulbus and gently bent (Fig. 167). Tibial apophysis originates at the mid-length of tibia, and is broadly bent initially (Fig. 168).

Female. Dorsal view shown in Fig. 166. Abdomen light with two darker streaks broken into 3 pairs of near-rectangular spots, there is a pair of lighter grey spots anteriorly, and a diamond-shaped, contrasting black spot at the posterior end of the abdomen. Epigyne broad, with pockets at the mid-point, widely spaced, translucent coils of copulatory ducts clearly half the length of the spermathecae (Fig. 170). Details of internal structure are shown in Fig. 171, and partially disentangled in Fig. 172.

REMARKS. Females are easier to identify and compare in Pseudicius, so a female is designated as the holotype. Figs 160-164 illustrate the differences in spermathecae and copulatory ducts in closely related species of Pseudicius, presumably reflecting changes during speciation on various islands: it appears that there are at least two species on Viti Levu in the Fijian Islands, the species from Savaii Island in Samoa is distinctly different from that from Java. Presumably there are more species in that area, and speciation in Pseudicius deserves closer scrutiny.

DISTRIBUTION. Documented from Indonesia: Java.

\section{Taraxella sumatrana Wanless, 1987} Figs 154-158.

T. s. Wanless, 1987: 125, f. 12A-J ( $\left.\sigma^{\top}+\right)$.

MATERIAL. + , Sumatra: Bohorok, 2 Jaunary, 1984. CDML.

REMARKS. This genus and its five species were described by Wanless [1984, 1987], from Borneo, Peninsula Malaya and Sumatra. The specimen illustrated here was collected in the "terra typica", but Wanless [1987: 125-127] does not list it in the original description. The females are known for only two of the spe- 
cies, but our drawing of the internal structure of epigyne is the first for the genus.

DIAGNOSIS. Epigyne with large translucent spermatheca, somewhat resembling a broad questioning mark, and a small, posterior depression. In the epigyne of T. petrensis Wanless, 1987, the translucent spermathecae are globular [Wanless, 1987: 124, f. 11D].

DESCRIPTION. A sufficient description of the general appearance of the female and its measurements were provided by Wanless [1987]. Body shape and pattern is shown in Figs 154-155. Epigyne with characteristic translucent internal parts, copulatory openings located on posterior rim of epigyne (Figs 156 157), in agreement with Wanless [1987: 126, f. 12D]. The spermatheca, drawn here for the first time, is beanshaped with two irregular protuberances (Fig. 158).

DISTRIBUTION. Documented from Indonesia: Sumatra.

\section{Genus Thianitara Simon, 1903}

Type species Thianitara spectrum Simon, 1903 from SE Asia.

DEFINITION. The genus Thianitara belongs to the subfamily Euophryinae. It has a flattened body with a broad carapace, holds long legs I outstretched anteriorly, flat and characteristically bent at the femur-patella joint (Figs 182-183). Tibia I has 5 pairs of ventral spines, metatarsus thin and long. Epigyne and palpus resembling those in Thiania.

REMARKS. This genus, originally described as monotypic, appears to be common in SE Asia [Murphy, 2000: pl. 30, f. 5], but nonetheless is poorly described. The original description [Simon, 1903a: 1054, f. 1122] is concise and illustrated only by a drawing of the distal segments of leg I. The only existing diagnostic drawings of the male palpus was given by Prószyński [1984: 147, f.?] who illustrated a non-type specimen of $T$. spectrum from Siboga, in the Reimoser collection; it is uncertain whether it is conspecific with the type. The only other existing illustrations of the genus Thianitara are diagnostic photo-documentation by $\mathrm{P}$. Koomen of specimens from Borneo, as well as a photograph of interacting males in Prószyński [2011].

Thianitara spectrum Simon, 1903

Figs 178-181, 182.

T. s. Simon, 1903a: 1054, f. $1122\left(\sigma^{7}\right)$.

T. s.: Prószyński, 1984a: $147\left(\bigcirc^{7}\right)$.

MATERIAL. $2 \sigma^{\top} \sigma^{\top}, 1$, Sumatra: Bohorok [several labels: "16 February", "10 March", "14 June 1983", "between 2 leaves glued together", "above bamboo", "from cave"]. CDML.

DIAGNOSIS. This species differs from Thiania bhamoensis Thorell, 1887 [Prószyński \& DeelemanReinhold, 2010: 181, figs 142-147] by having its body more flattened, five pairs of ventral spines on tibia I and in the shape of the genital organs (Figs. 178-182).

DESCRIPTION. Carapace flattened and broad (Fig. 182), with anterior part of carapace rectangular. Leg I large, held outstretched horizontally, bent at the femurpatella joint, with patella and tibia parallel to body axis. Tibia I with five pairs of ventral spines, metatarsus and tarsus I distinctly thinner than tibia I. There is a white mark basally on tibia I. Bulbus broad, embolus broad, course of spermophor compact, tibial apophysis terminates with a small hook (Figs 178-179).

Female (first description). Somatic characters are not documented. Epigyne with two large, oval "windows", separated by thin septum, which expands posteriorly (Fig. 180). Spermathecae globular, located posteriorly, copulatory ducts broad, overlapping part of spermathecae and about as long, directed diagonally (Fig. 181), their posterior part narrower, but thickwalled, makes a turn of 270 degrees before joining the spermathecae. The armature of the scent gland opening prominent and robust, set at the bend of the copulatory ducts.

DISTRIBUTION. Documented from Indonesia: Sumatra.

\section{Thianitara thailandica $\mathbf{s p . n .}$} Figs 183-186.

Thianitara sp.: Prószyński, 1992: 113, f. 121-124 (†).

MATERIAL. + holotype. Thianitara sp. Thailand: E slope of Doi Sutep, 875-950 m, 15 July, 1962. Leg. E.S. Ross \& D.H. Kavanaugh. CAS.

ETYMOLOGY. Named for country where collected.

DIAGNOSIS. This species differs from $T$. spectrum by the crescent-shaped sclerotization of the copulatory openings (Fig. 185) and the short copulatory duct, anterior to the spermatheca (Fig. 186).

DESCRIPTION. Male unknown. Female. Carapace broad, flat and low (Fig. 184), posterior half of abdominal pattern with broad dark transverse band, accompanied by thinner white bands (Fig. 164). Leg I longest, with tibia robust, swollen and armoured with 5 pairs of ventral spines, metatarsus I about as long as tibia, but thin (Fig. 183). Copulatory openings in the shallow anterior depression of the epigyne, their posterior rims forming a sclerotized crescent (Fig. 185). Spermathecae globular, copulatory channels short (Fig. 186), running diagonally, scent gland opening under sclerotized rims of the copulatory opening.

Measurements : length of carapace 2.37, length of abdomen 2.87 , length of eye field 1.0 , height of carapace 0.62 , width of eye field at eyes I 1.56 , width of eye field at eyes III 1.56, width of carapace at eyes III 1.75 .

REMARKS. This description complements the preliminary description by Prószyński [1992a: 113, f. 121-122], who did not propose a specific name for this species, due to uncertain generic placement. There was no female of any Thianitara known at that time for comparative purposes. Discovery of the female of $T$. spectrum from Sumatra (see above) has helped to bridge that gap. The problem of differentiating the genera Thianitara and Thiania C.L. Koch, 1846 deserves further study. 


\section{DISTRIBUTION. Documented from Thailand.}

ACKNOWLEDGMENTS. We are grateful to the late Suharto Djojosudharmo who collected spiders in many parts of Indonesia, during the years 1983-2000, kept now in the C.L. Deeleman-Reinhold collection, including those mentioned in this paper.

Permissions to reproduce a few comparative drawings from were received from Dr. M. Żabka. Very considerable editorial help was received from Dr. Yu.M. Marusik. Coquille paper for drawings was donated by Dr. W.P. Berry. The translation into English language was corrected by Dr. David Penney. Writing of this paper was assisted by special grant N303341235 from the Ministry of Higher Education and Sciences of Poland, and also by administrative help by the Museum and Institute of Zoology, Polish Academy of Sciences in Warsaw.

The authors express their sincere and warm thanks to the above mentioned persons and institutions.

\section{References}

Barrion A.T., Litsinger J.A. 1995. Riceland Spiders of South and Southeast Asia. Wallingford, UK: CAB International + International Rice Research Institute. 700 pp.

Benjamin S.P. 2004. Taxonomic revision and phylogenetic hypothesis for the jumping spider subfamily Ballinae // Zool. J. Linn. Soc. Vol.142. P.1-82.

Benjamin S.P. 2010. Revision and cladistic analysis of the jumping spider genus Onomastus (Araneae: Salticidae) // Zoological Journal of the Linnean Society, London. Vol.159. P.711745.

Berland L. 1929. Araignees (Araneida) // Insects of Samoa and other Samoan terrestrial Arthropoda. Vol.8. No.2. P.35-78.

Berry J.W., Beatty J.A., Prószyński J. 1997. Salticidae of the Pacific Islands. II. Distribution of Nine Genera, with Description of New Species // J. Arachnol. Vol.25. No.2. P.109-136.

Berry J.W., Beatty J.A., Prószyński J. 1998. Salticidae of the Pacific Islands. III. Distribution of Seven Genera, with Description of Nineteen New Species and Two New Genera // J. Arachnol. Vol.26. No.2. P.149-189.

Bryant E.B. 1940. Cuban spiders in the Museum of Comparative Zoology // Bull. Mus. Comp. Zool., Harv. Univ. Vol.86. P.247-554.

Davies V.T., Żabka M. 1989. Illustrated keys to the genera of jumping spiders (Araneae: Salticidae) in Australia // Mem. Queensl. Mus. Vol.27. No.2. P.189-266.

Doleschall C.L. 1859. Tweede Bijdrage tot de Kennis der Arachniden van den Indischen Arachipel // Acta Societatis scientiarum Indo-Neerlandicae. Vol.5. P.1-60.

Franganillo P. 1930. Aracnidos de Cuba. Mas Aracnidos nuevos de la Isla de Cuba // Mem. Instituto nacional de investigaciones cientificas, La Habana. Vol.1. P.47-99.

Ikeda H. 1998. Spiders of the genus Laufeia (Araneae: Salticidae) from Japan // Acta arachnologica. Vol.47. N.1. P.37-43.

Jastrzębski P. 1997. Salticidae from the Himalaya. Subfamily Spartaeinae Wanless, 1984 (Araneae, Salticidae) // Genus. Vol.8. Nos 3-4. P.701-713.

Koch C.L. 1846. Die Arachniden. Nürnberg. Bd.13. 234 S

Koomen P. Unpublished diagnostic photo-documentation by Koomen. Displayed on Prószyński 2011, online. (http:// www.gsd-salt.miiz.waw.pl/specimen.php?id=1584).

Logunov D.V., Azarkina G.N. 2008. Two new genera and species of Euophryinae (Aranei: Salticidae) from SE Asia // Arthropoda Selecta. Vol.17. No. 1-2. P. 111-115.

Maddison W.P. 1987. Marchena and other jumping spiders with an apparent leg-carapace stridulatory mechanism (Araneae: Salticidae: Heliophaninae and Thiodininae) // Bull. Brit. arachnol. Soc. Vol.7. P.101-106.
Maddison W.P., Bodner M.R., Needham K.M. 2008. Salticid spider phylogeny revisited, with the discovery of a large Australasian clade (Araneae: Salticidae) // Zootaxa. No.1893. P.49-64.

Marples B.J. 1957. Spiders from some Pacific islands // Pacif. Sci. Vol.11. P.386-395

Marples B.J. 1964. Spiders from some Pacific islands, part V // Pacif. Sci. Vol.18. P.399-410.

Murphy F., Murphy J. 2000. An introduction to the spiders of South East Asia. Malaysian Nature Society. Singapore. 624 pp.

Peckham G.W., Peckham E.G. 1885 [1886]. Genera of the family Attidae: with a partial synonymy // Trans. Wisconsin Acad. Sci., Arts and Letters. Vol.6. P.255-342.

Peckham G.W., Peckham E.G. 1907. The Attidae of Borneo // Trans. Wisconsin Acad. Sci., Arts and Letters. Vol.15. P.603-653.

Petrunkevitch A. 1930. The spiders of Porto Rico. Part three // Trans. Connecticut Acad. Arts and Sci. Vol.31. P.1-191.

Platnick N.I. 2011. The world spider catalog, version 11.5. American Museum of Natural History, online at http:// research.amnh.org/iz/spiders/catalog.

Próchniewicz M. 1990. Salticidae aus Nepal and Bhutan. Genera Telamonia Thorell 1887 und Plexippoides Prószyński 1976 (Arachnida: Araneae) // Senckenberg. biol. Vol.70. No.1/3. P.151-160.

Prószyński J. 1968. Redescriptions of type-species of genera of Salticidae (Araneida). III. Remarks on the genera Gelotia Thorell, 1890 and Policha Thorell, 1892 // Ann. Mus. civ. Stor. nat., Genova. Vol.77. P.16-20.

Prószyński J. 1971. Catalogue of Salticidae (Aranei) specimens kept in major collections of the world // Ann. Zool., Warszawa. T.28. P.367-519.

Prószyński J. 1976. Studium systematyczno-zoogeograficzne nad rodzina Salticidae (Aranei) Regionow Palearktycznego i Nearktycznego. Rozprawy Wyższej Szkoły Pedagogicznej. Siedlce. T.6. $260 \mathrm{pp}$.

Prószyński J. 1983. Redescriptions of types of Oriental and Australian Salticidae (Araneae) in Hungarian Natural History Museum in Budapest // Fol. entomol. hung. T.44. No.2. P.283-297.

Prószyński J. 1984a. Remarks on Viciria and Telamonia (Araneae, Salticidae) // Ann. Zool., Warszawa. T.37. No.18. P.418-436.

Prószyński J. 1984b. Atlas rysunkow diagnostycznych mniej znanych Salticidae // Zeszyty Naukowe WSRP, Siedlce. 177 pp.

Prószyński J. 1987. Atlas rysunków diagnostycznych mniej znanych Salticidae 2. Siedlce: Zeszyty Naukowe WSRP. 172 pp.

Prószyński J. 1989. Salticidae (Araneae) of Saudi Arabia // Fauna of Saudi Arabia. Vol.10. P.31-64.

Prószyński J. 1992. Salticidae (Araneae) of the Old World and Pacific Islands in several US collections // Ann. Zool., Warszawa. T.44. No.8. P.87-163.

Prószyński J. 2003. Salticidae (Araneae) of the Levant // Ann. Zool., Warszawa. T.53. No.1. P.1-180.

Prószyński J. 2011. Monograph of Salticidae (Araneae) of the World. Internet, version 2011. http:/www.miiz.waw.pl/salti$\mathrm{cid} / \mathrm{main} . \mathrm{htm}$, online [version summing up previous versions since 1995].

Prószyński J., Deeleman-Reinhold C.L. 2010. Description of some Salticidae (Araneae) from the Malay Archipelago. I. Salticidae of the Lesser Sunda Islands, with coents on related species // Arthropoda Selecta. Vol.19. No.3. P.153-188.

Roewer C.F. 1954. Katalog der Araneen von 1758 bis 1940. Bruxelles. Vol.2b. P.927-1751.

Simon E. 1868. Monographie des espèces européennes de la famille des Attides (Attidae Sundewall - Saltigradae Latreille) // Ann. Soc. Entomol. France. T.4. No.8. P.11-72, 529-726.

Simon E. 1889. Etudes arachnologiques. 21e Memoire. XXXIII. Descriptions de quelques espèces recueillies au Japan, par A. Mellotee // Ann. Soc. Entomol. France. T. 6. No.8. P.248-252.

Simon E. 1890. Etudes arachnologiques. 22e Memoire. XXXIV. Etude sur les Arachnides de 1'Yemen // Ann. Soc. Entomol. France, Paris. Ser.6. T.10. P.77-124.

Simon E. 1899. Contribution a la faune de Sumatra. Arachnides recueillis par M. J. L. Weyers, a Sumatra. (Deuxieme memoire) // Ann. Soc. Entomol. Belgique. T.43. P.78-125. 
Simon E. 1900. Etudes arachnologiques. 30e Memoire. XLVII. Description d'espèces nouvelles de la famille des Attidae // Ann. Soc. Entomol. France. T.69. P.27-61.

Simon E. 1901. Histoire Naturelle des Araignées. Paris. T.2. No.3. P.381-668.

Simon E. 1902. Etudes arachnologiques. 32e. Memoire. LI. Descriptions d'espèces nouvelles de la famille des Salticidae (suite) // Ann. Soc. Entomol. France. T.71. P.389-421.

Simon E. 1903a. Histoire Naturelle des Araignées. Paris. T. 2. Nos 3-4. P.669-1080

Simon E. 1903b. Etudes arachnologiques. 34e Mémoire. LIV. Arachnides recueillis a Sumatra par M. J. Bouchard // Ann. Soc. Entomol. France. T.72. P.301-310.

Song D., Gu M., Chen Z. 1988. Three new species of the family Salticidae from Hainan, China // Bull. Hanggzhou Normal College. (Nat. Sci.). No.6. P.70-74.

Strand E. 1932. Miscellanea nomenclatorica zoologica et palaeontologica, III // Fol. zool. hydrobiol. Vol.3. P.133-147.

Thorell T. 1887. Viaggio di L. Fea in Birmania e regioni vicine. II. Primo saggio sui ragni birmani // Ann. Mus. civ. Stor. natur. Genova. T.25. P.5-417.

Thorell T. 1890. Diagnoses aranearum aliquot novarum in IndoMalesia inventarum // Ann. Mus. civ. Storia natur. Genova. T.30. P.132-172.

Thorell T. 1892. Studi sui Ragni Malesi e Papuani. IV, 2 // Ann. Mus. civ. Stor. natur. Genova. T.31. P.1-490.

Thorell T. 1895. Descriptive Catalogue of the Spiders of Burma. London. 406 pp

Useta G., Huber B.A., Costa F.G. 2007. Spermathecal morphology and sperm dynamics in the female Schizocosa malitiosa (Araneae: Lycosidae) // Eur. J. Entomol. Vol.104. P.777-785.

Walckenaer C.A. 1802. Faune parisienne. Insectes ou Historie parisienne. Insectes des environs de Paris. T.2. P.187-250.
Wanless F.R. 1978. A revision of the spider genus Marengo (Araneae: Salticidae) // Bull. Brit. Mus. (Nat. Hist.) (Zoology series). Vol.33. No.4. P.259-278.

Wanless F.R. 1981. A revision of the spider genus Phaeacius (Araneae, Salticidae) // Bull. Brit. Mus. (Nat.1 Hist.) (Zoology series). Vol.41. N.4. P.199-219.

Wanless F.R. 1983. Araneae-Salticidae. Contributions a l' etude de la faune terrestre des iles granitiques de 1' archipel des Sechelles // Ann. Mus. roy. Afrique Centr. Serie in 8, Tervuren. No.241. P.1-84.

Wanless F.R. 1984. A review of the spider subfamily Spartaeinae nom. n. (Araneae, Salticidae) with descriptionof six new genera // Bull. Brit. Mus. (Nat. Hist.) (Zoology series). Vol.46. No.2. P.135-198.

Wanless F.R. 1987. Notes on spiders of the family Salticidae. 1. The genera Spartaeus, Mintonia and Taraxella // Bull. Brit. Mus. (Nat. Hist.) (Zoology series). Vol.52. No.3. P.107-137.

Wesołowska W., Russel-Smith A. 2011. Jumping spiders (Araneae: Salticidae) from Southern Nigeria // Ann. Zool., Warszawa. Vol.61. No.3. P.554-619.

Żabka M. 1985. Systematic and zoogeographic study on the family Salticidae (Araneae) from Viet-Nam // Ann. Zool., Warszawa. T.39. No.11. P.197-485.

Zabka M. 1988. Salticidae (Araneae) of Oriental, Australian and Pacific Regions III // Ann. Zool., Warszawa. T.41. No.14. P.421-479.

Żabka M. 1992. Orsima Simon (Araneae: Salticidae) a remarkable spider from Africa and Malaya // Bull. Brit. Arachnol. Soc. Vol.9. Pt.1. P.10-12.

Zhang J.X., Song D.X., Li D.Q. 2003. Six new and one newly recorded species of Salticidae (Arachnida. P. Araneae) from Singapore and Malaysia // Raffles Bull. Zool. Vol.51. No.2. P.187-195

Responsible editor Yu.M. Marusik 